\title{
Investigation and assessment of supplied water quality in Rajshahi City Corporation of Bangladesh
}

\author{
Saleha Akhter Poly ${ }^{1}$, Arif Hasnat ${ }^{1}$, Hasib Imran Tusher ${ }^{1}$, H. M. Rasel ${ }^{1}$ \\ ${ }^{1}$ Department of Civil Engineering, Rajshahi University of Engineering \& Technology, Rajshahi, Bangladesh \\ Correspondence to: Hasib Imran Tusher (imranhasibce99ruet15@gmail.com)
}

\begin{abstract}
This paper has investigated the extensive implementation of distinct types of pipes in the Water Distribution System (WDS) and evaluated the impacts of particular leachable organic chemicals and bacteriological issues. Besides, the paper inspects significant water quality parameters like the population of Rajshahi City, Bangladesh relies on water provided via pipes for drinking and other domestic purposes. This study aims to assess the quality of physical, chemical, and microbiological parameters of supplied drinking water through lines in Rajshahi City Corporation (RCC) by Rajshahi Water Supply and Sewerage Authority (RWASA). Therefore, the study managed sixteen physical, chemical, and microbiological parameters to analyse them in the laboratory. The experimental results showed that all samples' $\mathrm{pH}$ and hardness were within the allowable limit as per Bangladesh Drinking Water Standards (BDWSs) and World Health Organization (WHO). All models contained an extreme level of iron and manganese. They also included a negligible amount of arsenic. The experiment detected lesser Dissolved Oxygen (DO), Residual Chlorine (Residual Cl), and the undesirable odour in about $90 \%$ samples. All samples contained Total Coliform (TC) and Escherichia coli (E. coli) bacteria. A few samples contained a significant amount of turbidity, Chemical Oxygen Demand (COD), Biological Oxygen Demand (BOD), and Electrical Conductivity (EC). The authors developed a statistical analysis by SPSS software to co-relate the parameters. This study recommends the presence of such bacteria, iron, and manganese in the pipeline.
\end{abstract}

Keywords. Water quality, Investigation, Physical parameters, Chemical parameters, Microbiological parameters, Health risks

\section{Introduction}

Good quality of drinking water is one of the critical components of human physiology (Etim et al., 2013). So, water is one of the essential substances for sustaining life, health, and preserving ecosystems (Cabral, 2010; AL-Dulaimi and Younes, 2017). However, ensuring safe drinking water with adequate quantity to the consumers is the major challenge in the last decades. Because, water demand, as well as water degradation, have been rising due to the growing population, land exploitation, overexploitation of groundwater and economic development in the last century (Chalchisa et al., 2017; Kumar et al., 2017; Lee et al., 2018; Robinne et al., 2018). Developing countries use improved drinking water (Piped water supply) sources as an alternate option to mitigate and fulfil the consumers' water demand.

Rajshahi Water Supply and Sewerage Authority (RWASA) was established in 2012 as an improved water source to overcome the water crisis due to the population increase in Rajshahi City Corporation (RCC). RWASA provides water to the 
https://doi.org/10.5194/dwes-2020-31

Preprint. Discussion started: 13 January 2021

(c) Author(s) 2021. CC BY 4.0 License.

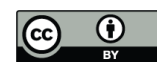

$40 \%$ households of the city. Currently, RWASA faces improving the quality of supplied water to the customers, as RWASA could not serve water satisfactorily to its consumers. People found blackish and reddish water due to high-level manganese 40 and iron and complained about water quality during the field survey. The supplied water by RWASA contains physical, chemical, and microbiological parameters apart from the presence of manganese and iron. However, field specialists have not studied these parameters.

Nowadays, the water quality problem is one of the most significant problems in developing countries like Bangladesh (Akoto et al., 2017). Again, drinking water is a potential vehicle of exposure to both physical and chemical contaminants. The 45 contaminants may occur naturally or artificially (Fernández-Navarro et al., 2017). Liu et al. (2017c) inspected many potentially leachable substances from pipes with the widespread application of different categorical pipes in Drinking Water Distribution Systems (DWDSs). Contaminants can enter into the Water Distribution System (WDS) due to human activity (Anthropogenic contaminants), locally available materials (Natural contaminants like Fe, Mn, and As), and pharmaceuticals (Benson et al., 2017; Liu et al., 2017a). Additionally, the intermittent water supply system is another major cause to degrade water quality

50 (Agathokleous and Christodoulou, 2016; Erickson et al., 2017; Vairavamoorthy et al., 2007). The first one is the treatment process from Anthropogenic contaminants, including coagulation-flocculation, disinfection, disinfection by-products, filtration, adsorption, and sedimentation. Such processes produce contaminants. As a result, they incorporate with supplied water. The second type contaminants (Zinc or Cadmium) incorporate with drinking water during distribution and storage.

Poorly designed, constructed, and operated water systems deteriorate the water quality in the distribution system resulting 55 in consumer complaints (Doull et al., 1982). Source water, supply infrastructure, and the supply system's operation influence the formation of biofilm in DWDSs (Douterelo et al., 2016). It is unnecessary to say that biofilms alter and degrade water quality (Liu et al., 2017b). Biofilm influences to increase bacterial counts or regrowth in the distribution system resulting from detachment of bacteria from the biofilm, reduce Dissolved Oxygen (DO) content resulting from microbial activity in the biofilm, taste and odour changes resulting from products of microbial metabolism within the biofilm, red water resulting from

60 the activity of iron bacteria and increased hydraulic roughness. From another literature review, pipe materials (Wang et al., 2018), type of surface materials, the interaction between the disinfectants (Zhang et al., 2017), hydrodynamics, water temperatures, and residual disinfectants are another factors to influence the biofilm formation, taste, and odour (Zhou et al., 2017).

The study collected fifty-six water samples based upon public objections from fourteen wards out of thirty wards to 65 investigate the harmful contaminants. The authors performed the analysis of physical, chemical, and microbiological parameters like pH, turbidity, Electrical Conductivity (EC), hardness, heavy metals (Iron, Arsenic, and Manganese), DO, odour, temperature, Chemical Oxygen Demand (COD), Biological Oxygen Demand (BOD), Residual Chlorine (Residual Cl), Escherichia coli (E.coli), and Total Coliform (TC) in the laboratory following the standard procedures. Nevertheless, the experimental results were not satisfactory. Investigating public opinion and lab tests, the concentration of manganese and iron

70 was extreme. Arsenic presented in water in a negligible amount. Other targeted parameters deviated from the World Health Organization (WHO) standards and Bangladesh Drinking Water Standards (BDWSs) in some samples. Even the microbiological parameters did not give a satisfactory report. Elevated concentration of manganese, iron and their consumption in extreme amount cause severe health problems (Memon et al., 2011).

The authors also checked the essential physical and chemical parameters to understand the significance of local consumers'

75 water quality issues. This study aims to measure the deterioration of water quality flowing from sources to the consumers. This knowledge will be more useful for the professionals of water quality sectors and use as a reference for the city's drinking water quality. Furthermore, the study attempts to help the RCC and RWASA delivering salient information regarding the present quality of supplied water in the city and make them cautious of supplying good quality water. 


\section{Research methodology}

\subsection{Description of the sampling site}

RCC is one of the twelve city corporations, located in the north-west part of Bangladesh. It lies between $24^{0} 21^{\prime}$ and $24^{0} 26^{\prime} \mathrm{N}$ latitude and between $88^{\circ} 28^{\prime}$ and $88^{\circ} 37^{\prime}$ E longitude. The city is bounded on the east, north, and west by Paba Thana, and the south by the Padma River with about 47.78 square km (Rahman, 2004). RCC consists of 30 wards, as shown in Fig. 1.

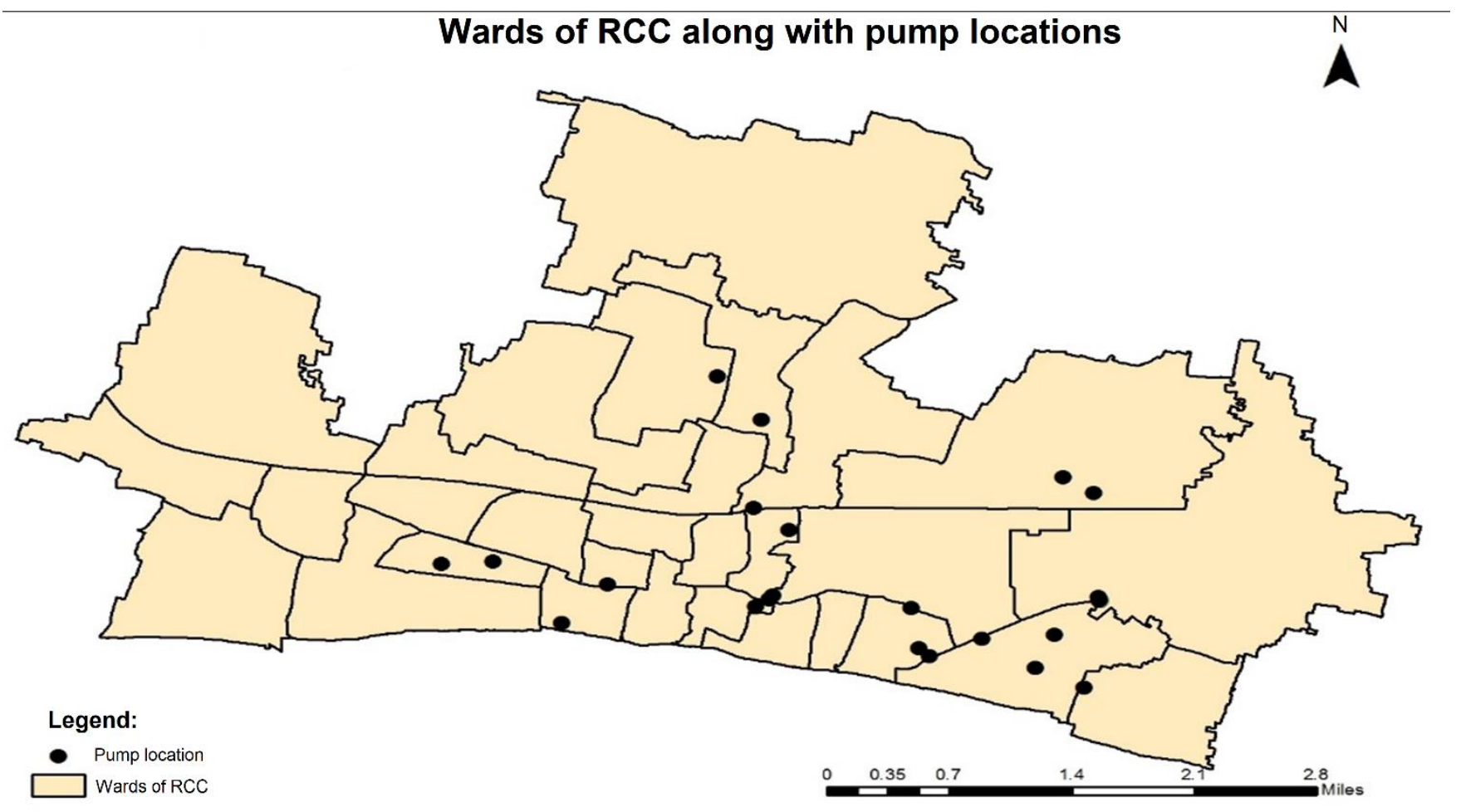

Figure 1: Study area (Source: Prepared by author).

\subsection{Field survey}

The authors conducted a questionnaire survey from people of the selected wards of RCC to know their concern about the significance of drinking water quality problems. They incorporated the questionnaire survey with questions on the water body, location, population of the village, common diseases in the locality, availability, and quality of drinking water (Alom and Habib, 2016). 


\subsection{Collection and preservation of water samples}

The authors selected fourteen wards out of thirty wards of RCC for the investigation based on the public's water quality problems. The investigation mainly covered the central part of the city. They selected three consumers (S1, S2, and S3) points for each water source. They characterised fifty-six samples in total and surveyed the wards to evaluate water quality parameters. The authors collected samples in clean new $200 \mathrm{~mL}$ sterile bottles with corks that they pre-treated the bottles through washing with dilute $\mathrm{HCl}$ and later rinsed them with distilled water (Oyem et al., 2014). The testers then air-dried them in a dust-free environment.

\subsection{Lab analysis}

Table 1: Experimental methods for different types of parameters with their BDWSs and WHO standards.

\begin{tabular}{|c|c|c|c|c|}
\hline Type and name o & arameters & $\begin{array}{l}\text { Methods or machines } \\
\text { used }\end{array}$ & WHO standards & BDWSs \\
\hline \multirow{7}{*}{ Physical parameters } & $\mathrm{pH}$ & $\mathrm{pH}$ meter & $6.5-8.5$ & $6.5-8.5$ \\
\hline & Turbidity & Turbidity meter & $5 \mathrm{NTU}$ & $10 \mathrm{NTU}$ \\
\hline & Conductivity & Conductivity meter & -- & $1200 \mu \mathrm{s} \mathrm{cm}^{-1}$ \\
\hline & Temperature & Multi-parameter & $20-30{ }^{\circ} \mathrm{C}$ & $20-30{ }^{\circ} \mathrm{C}$ \\
\hline & DO & Multi-parameter & -- & $6 \mathrm{mg} \mathrm{L}^{-1}$ \\
\hline & Colour & Spectrophotometer & -- & 15 Hazen \\
\hline & Odour & Threshold method & Odourless & Odourless \\
\hline \multirow{7}{*}{$\begin{array}{l}\text { Chemical } \\
\text { parameters }\end{array}$} & Manganese & $\begin{array}{c}\text { UV-VIS } \\
\text { spectrophotometer }\end{array}$ & $0.5 \mathrm{mg} \mathrm{L}^{-1}$ & $0.1 \mathrm{mg} \mathrm{L}^{-1}$ \\
\hline & Arsenic & & $0.01 \mathrm{mg} \mathrm{L}^{-1}$ & $0.05 \mathrm{mg} \mathrm{L}^{-1}$ \\
\hline & Iron & Titration method & $0.3-1 \mathrm{mg} \mathrm{L}^{-1}$ & $0.3 \mathrm{mg} \mathrm{L}^{-1}$ \\
\hline & BOD & & -- & $0.2 \mathrm{mg} \mathrm{L}^{-1}$ \\
\hline & COD & & -- & $4 \mathrm{mg} \mathrm{L}^{-1}$ \\
\hline & Residual Cl & & -- & 0.2 \\
\hline & Hardness & & -- & $200-500 \mathrm{mg} \mathrm{L}^{-1}$ \\
\hline \multirow{2}{*}{ Biological parameters } & $\mathrm{TC}$ & $\begin{array}{l}\text { Membrane Filtration } \\
\text { Method (MFM) }\end{array}$ & $0 \mathrm{CFU}(100 \mathrm{~mL})^{-1}$ & $0 \mathrm{CFU}(100 \mathrm{~mL})^{-1}$ \\
\hline & E. coli & $\begin{array}{l}\text { Multiple tubes (MPN) } \\
\text { method }\end{array}$ & $0 \mathrm{CFU}(100 \mathrm{~mL})^{-1}$ & $0 \mathrm{CFU}(100 \mathrm{~mL})^{-1}$ \\
\hline
\end{tabular}

\subsection{Immediate analysis}

The authors tested the collected water samples immediately after collecting samples for some physical parameters, including EC, pH, turbidity, and temperature (Martínez-Santos et al., 2017). They measured almost all these vital water quality 
https://doi.org/10.5194/dwes-2020-31

Preprint. Discussion started: 13 January 2021

(c) Author(s) 2021. CC BY 4.0 License.

(c) (i)

parameters within four hours of collection due to obtaining an accurate value (Fahmida et al., 2013). The testers thoroughly rinsed all probes of multi-parameter and wholly dried them with lint-free wipes or compressed air. The recommended order for calibration of the individual probes on a multi-parameter is EC, $\mathrm{pH}$, and Turbidity (Guidelines for drinking-water quality, 2004).

\section{Results and discussion}

WHO standards and BDWSs evaluated the present quality of supplied water and the degree of water bodies' pollution. The authors studied the collected data with a statistical model developed by SPSS software (J et al., 2012).

\subsection{General analysis}

\subsubsection{Analysis of physical parameters}

pH: It specifies the degree of acidity or alkalinity of water (Guettaf et al., 2017). The laboratory experiment found that $\mathrm{pH}$ values ranged from 6.4-7.5 following the BDWSs and WHO standards. Figure 2(a)

Turbidity: $50 \%$ of the customers had turbidity higher than the acceptable value. Higher turbidity values were typical of consumers where source water satisfied allowable limit (WHO standards and BDWSs). The maximum value was 25.22 NTU in ward 25 (S2), which means about five times WHO standards. Excessive turbidity or cloudiness in drinking water is

120 aesthetically unappealing and represents a health concern. Turbidity can provide food and shelter for pathogens (Turbidity and water). From the laboratory analysis, the turbidity range for supplied water lied between 0.41-25.22 NTU. Although source water satisfies BDWSs and WHO standards, water contamination occurs during transport, storage with intermittent water supply (Edokpayi et al., 2018; Falconi et al., 2017). Figure 2(b)

Temperature: Samples collected from RWASA and users had a temperature ranged from $16.5-30{ }^{\circ} \mathrm{C}$. Comparing BDWSs and WHO standards, the temperature of all samples satisfied BDWSs and WHO standards. However, it is not possible to measure the internal temperature of water within the pipe. Figure 2(c)

Dissolved Oxygen (DO): Almost all samples, both sources and consumers had a lower amount of DO and ranged from 0.19-3.5 mg L $\mathrm{L}^{-1}$. The experimental results measured a declination of DO when water travelled from source to household premises in maximum wards. Figure 2(d)

130 The higher value of DO in water than the traditional values means the superior satisfactoriness of that water (Hossain et al., 2014). Higher BOD and COD indicate the lower DO. The lower DO indicates a higher amount of TC (Liyanage and Yamada, 2017).

Electrical Conductivity (EC): EC is the actual measure of a solution's ionic activity in terms of its capacity to transmit current (Mangi et al., 2017). The test results showed that the samples were high EC insoluble salts to the extent that except eight samples, almost all samples (Consumers and WASA) crossed BDWSs of $1200 \mu \mathrm{s} \mathrm{cm}^{-1}$. EC ranged from $450-1900 \mu \mathrm{s}$ $\mathrm{cm}^{-1}$. Maximum and minimum values were in the household points of ward 13 and the source of ward 30, respectively. Fortythree samples had the EC range of 1250-1900 $\mu \mathrm{s} \mathrm{cm}^{-1}$. Figure 2(e)

Odour: Out of fifty-six samples collected from the study area, the majority of about $90 \%$ had an objectionable odour. Odour problem creates due to minerals such as iron or copper, may leach into water from the pipes or due to bacteria growing in a pipe or from organic matter or bacteria that are naturally present in lakes, and reservoirs during the particular times of a year (Color, taste and odor problems in drinking water, 2018). Rest of the water samples was free from odour. Figure 2(f) 
Colour: Coloured water is not always harmful to man, but the disinfection of water by Chlorination contains natural organics that produce colour resulting in the formation of Chloroform. So it is crucial to limit the colour of water for domestic and other purposes (Bari and Sarkar, 2017). In this study, twelve water samples had colour values beyond the recommended

145 value of 15 Hazen. About forty-three samples had a colour range of 5-15 Hazen. Colour ranged from 5-20 Hazen. Ward 27, 29, and 12 had blackish, reddish, and black-reddish coloured water. They are metallic colours and represent high concentrated iron and manganese.

(a)

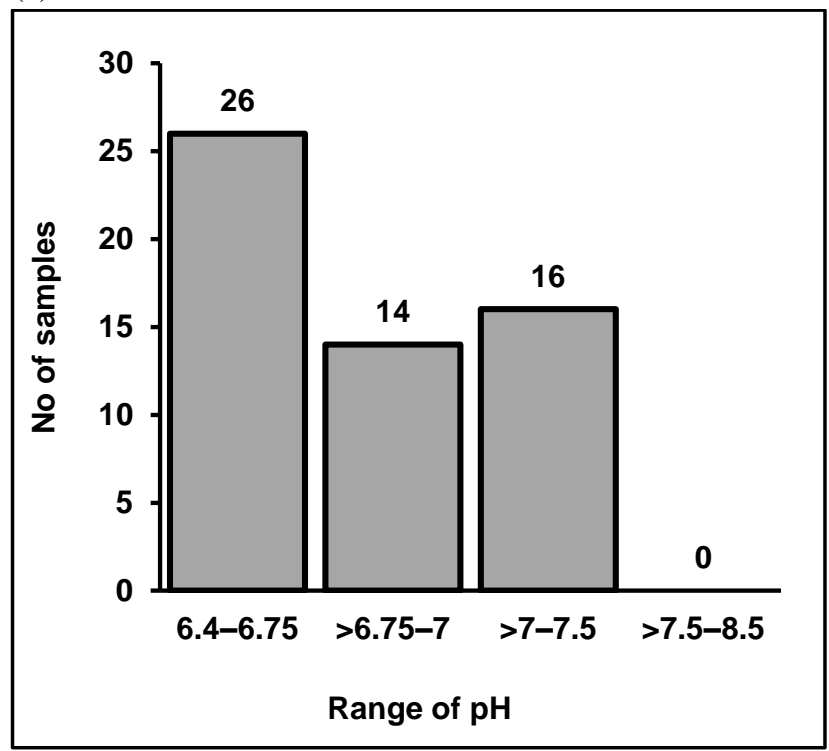

(c)

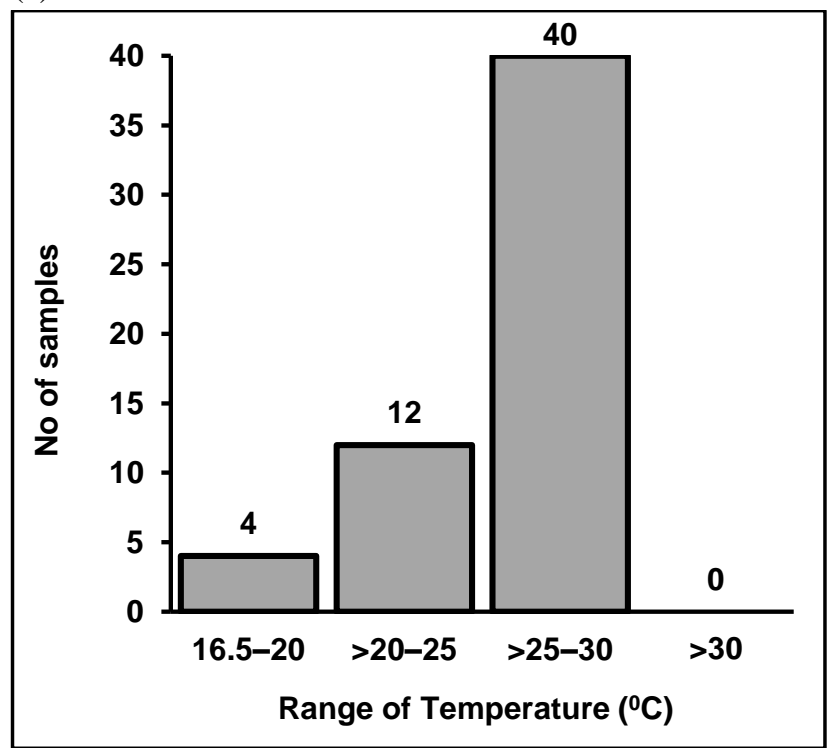

(b)

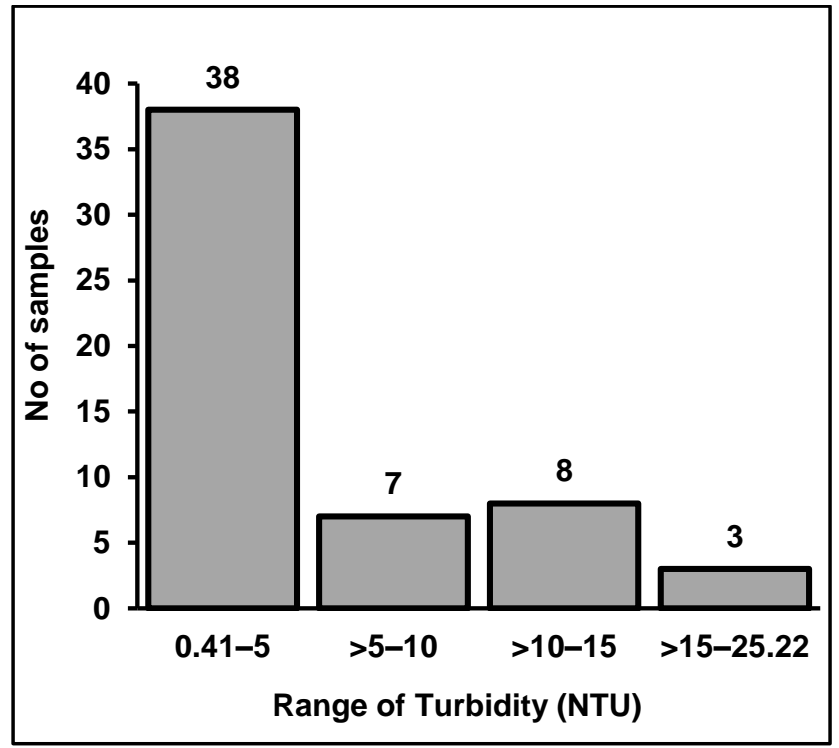

(d)

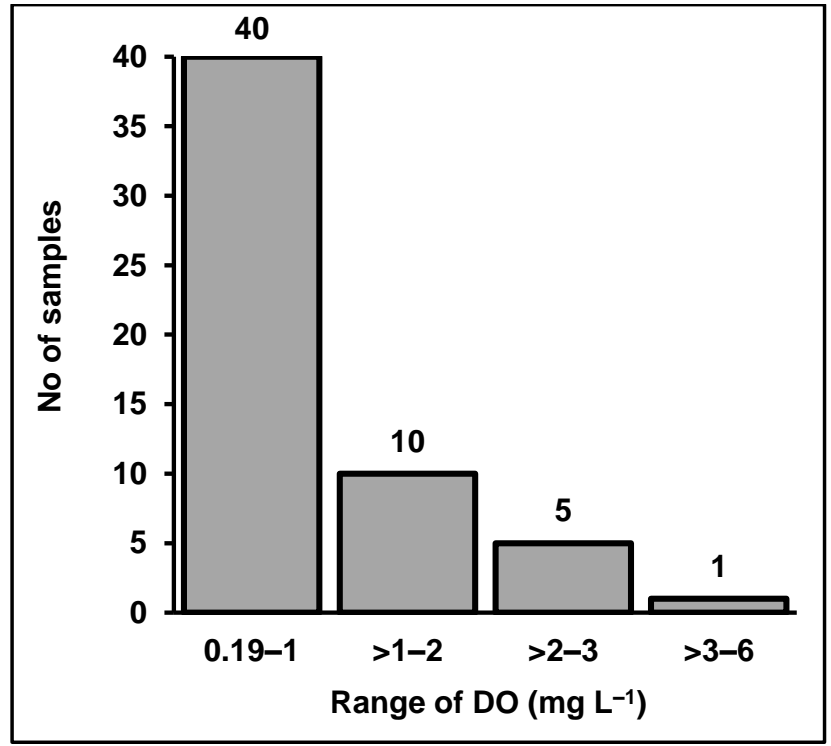


(e)

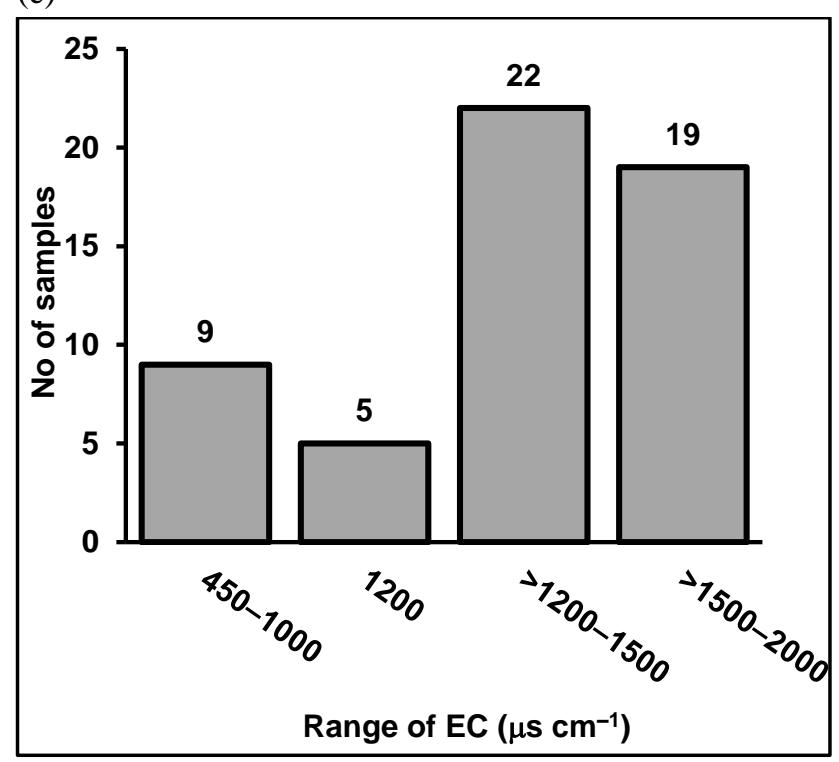

(f)

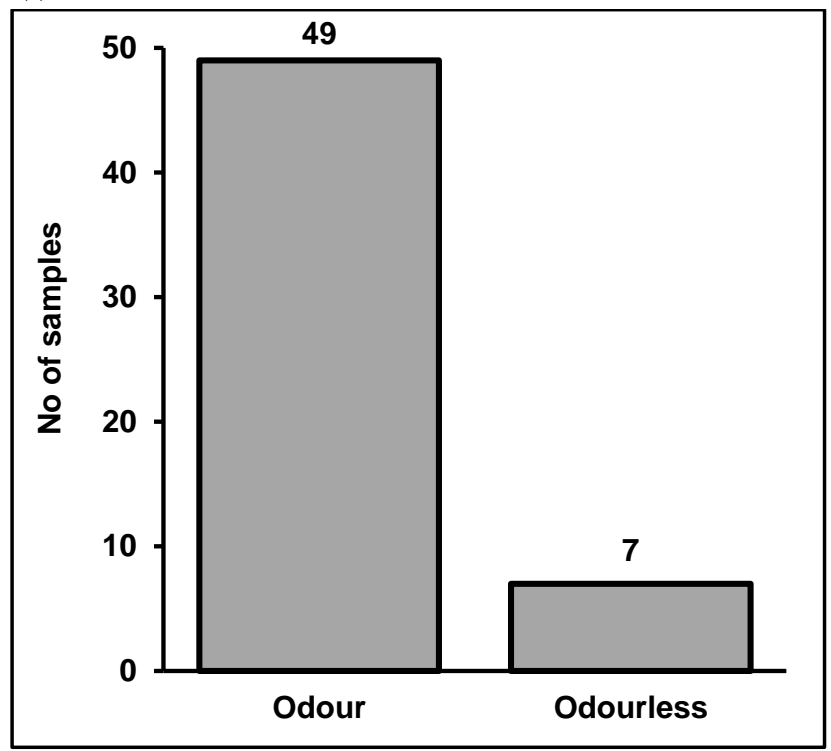

(g)

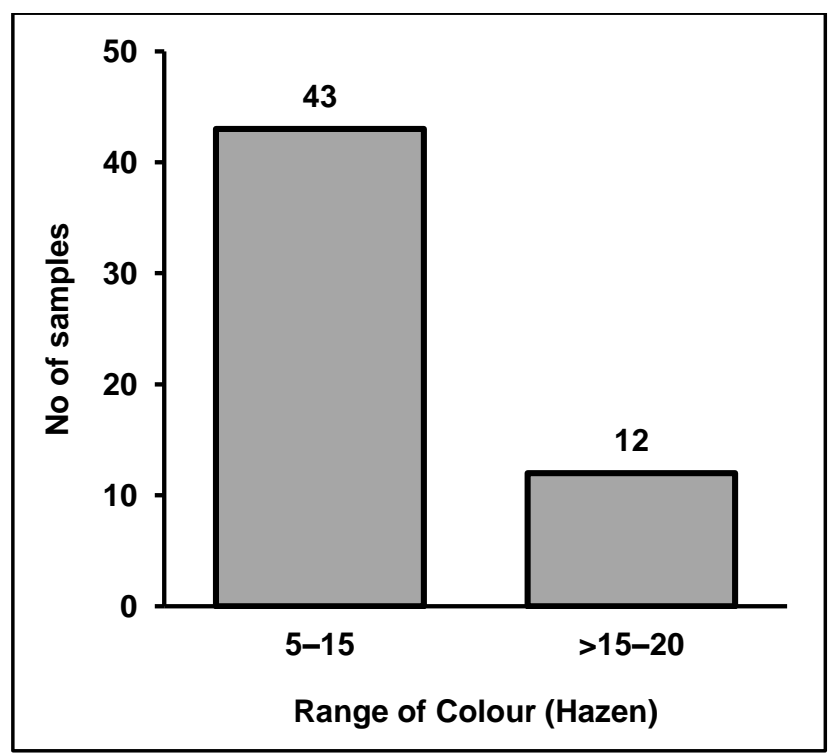

Figure 2: Representation of physical parameters: (a) pH, (b) Turbidity, (c) Temperature, (d) DO, (e) EC, (f) Odour/Odourless, and (g) Colour.

\subsubsection{Analysis of chemical parameters}

Heavy metal (Iron, Fe): In the study area, the laboratory tests found a maximum Fe concentration of $3.5 \mathrm{mg} \mathrm{L}^{-1}$ (Consumer S2 from ward 12), and a minimum concentration of $0.03 \mathrm{mg} \mathrm{L}^{-1}$ (Sources of ward 11). The experimental analysis 
found twenty-seven samples (Sources and users) above the permissible limit set by BDWSs. Nine samples had iron ranged from $0.03-0.2 \mathrm{mg} \mathrm{L}^{-1}$. Four samples were the same as the WHO standards. Twenty samples ranged from $>0.3-1 \mathrm{mg} \mathrm{L}^{-1}$. Rock structures of the area are responsible for the high concentration of iron in the supplied water (Shigut et al., 2017). Figure 3(a)

Heavy metal (Manganese, Mn): Mn highly polluted the study area. Almost all samples had Mn greater than the permissible limit of both WHO standards and BDWSs. The minimum and maximum Mn concentrations of $0.6 \mathrm{mg} \mathrm{L}^{-1}$ and 2.1 $\mathrm{mg} \mathrm{L}^{-1}$ were recorded in ward 8 (Consumers point S1) and ward 12 (Consumers point S2). Thirty-eight samples from both the consumers and the sources ranged from $0.60-1 \mathrm{mg} \mathrm{L}^{-1}$. The rest of the samples ( $\mathrm{S}$ and $\mathrm{U}$ ) had a range of 1.1-2.1 $\mathrm{mg} \mathrm{L}^{-1}$, which is highly toxic for the consumers. It is mainly due to the depth of water in contact with the area's rock surfaces. A high

175 concentrated $\mathrm{Fe}$ and $\mathrm{Mn}$ in ward 12 resulted in the black-reddish water, and the consumers complained due to the presence of such type of metallic colour in the water at the survey period. Figure 3(b)

Heavy metal (Arsenic, As): There was a negligible amount of As present in the selected wards. The amount of As in all wards is below the BDWSs. Thirty-one samples were free from As. Six samples were precisely similar to WHO standards and were $0.01 \mathrm{mg} \mathrm{L}^{-1}$. Eighteen samples were slightly higher than whom standards ranged from $0.015-0.03 \mathrm{mg} \mathrm{L}^{-1}$. The experiment found only one sample of $0.04 \mathrm{mg} \mathrm{L}^{-1}$ in ward 28. Figure 3(c)

Chemical Oxygen Demand (COD): COD is always higher than BOD. Out of fifty-six samples collected from the study area, twenty-three and six samples had the COD higher than the desirable level (BDWSs) of $4 \mathrm{mg} \mathrm{L}^{-1}$, ranging from 4.5-6 $\mathrm{mg}$ $\mathrm{L}^{-1}$, and 6.5-8 $\mathrm{mg} \mathrm{L}^{-1}$ respectively. The concentration of two samples was $4 \mathrm{mg} \mathrm{L}^{-1}$, similar to BDWSs. Twenty-five samples ranged from 1-3.5 $\mathrm{mg} \mathrm{L}^{-1}$ falling within the allowable range of BDWSs. Figure 3(d)

Biological Oxygen Demand (BOD): BOD ranged from 0.1-4 $\mathrm{mg} \mathrm{L}^{-1}$. Except for two samples $\left(0.1 \mathrm{mg} \mathrm{L}^{-1}\right.$ and $0.2 \mathrm{mg}$ $\mathrm{L}^{-1}$ ), all the samples exceeded the BDWSs. Higher BOD and COD indicate the presence of high-level microorganisms. Figure $3(\mathrm{e})$

Residual Chlorine (Residual Cl): Maximum concentration of Residual $\mathrm{Cl}$ was $1.13 \mathrm{mg} \mathrm{L}^{-1}$ at the source (Ward 9). Sixteen samples ranged from $0.1-0.17 \mathrm{mg} \mathrm{L}^{-1}$ lower than the BDWSs limit. Eight samples resulted in precisely similar to the BDWSs limit of $0.2 \mathrm{mg} \mathrm{L}^{-1}$. Sixteen samples ranged from $0.3-1.13 \mathrm{mg} \mathrm{L}^{-1}$. Fifteen samples had no Residual $\mathrm{Cl}$ (Ward 14 and 8). No Residual $\mathrm{Cl}$ and Residual $\mathrm{Cl}$ lower than BDWSs indicate the high amount of microorganisms. Figure 3(f)

Total hardness: Water can be soft $\left(<75 \mathrm{mg} \mathrm{L}^{-1}\right)$, moderately challenging $\left(75-150 \mathrm{mg} \mathrm{L}^{-1}\right)$, hard $\left(150-300 \mathrm{mg} \mathrm{L}^{-1}\right)$, and tough (>300 $\mathrm{mg} \mathrm{L}^{-1}$ ) according to the concentration of Calcium (Ca) and Magnesium (Mg) (Alam et al., 2017). Out of fourteen sources and forty-two users in the RCC area, two sources and seven consumers exceeded the allowable limit of BDWSs. Four samples collected from both the sources and the consumers fell within the soft category ranged from $45-70 \mathrm{mg} \mathrm{L}^{-1}$. Fourteen samples ranged from $75-150 \mathrm{mg} \mathrm{L}^{-1}$ fell within the moderate category. Nine samples ranged from $210-290 \mathrm{mg} \mathrm{L}^{-1}$ were in the hard category. Nevertheless, the rests were classified as very hard ranged from $347.2-650 \mathrm{mg} \mathrm{L}^{-1}$. Figure $3(\mathrm{~g})$ 
(a)

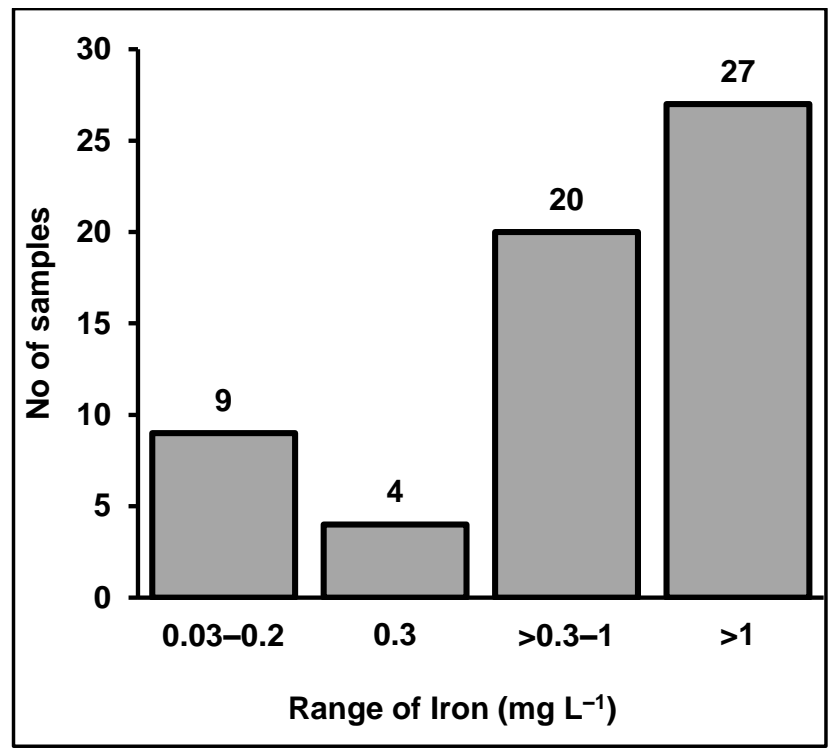

210

(c)

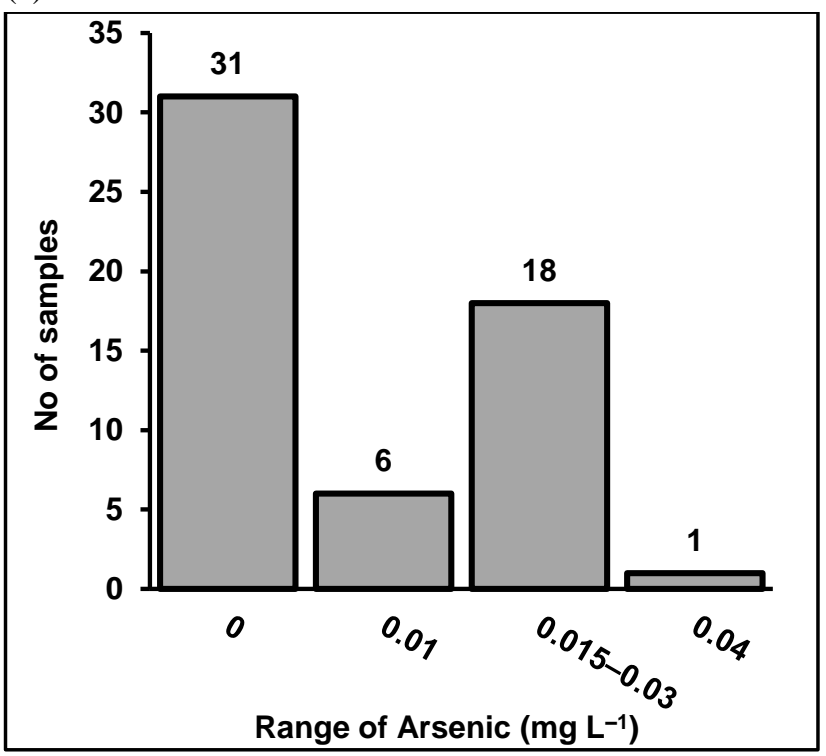

(b)

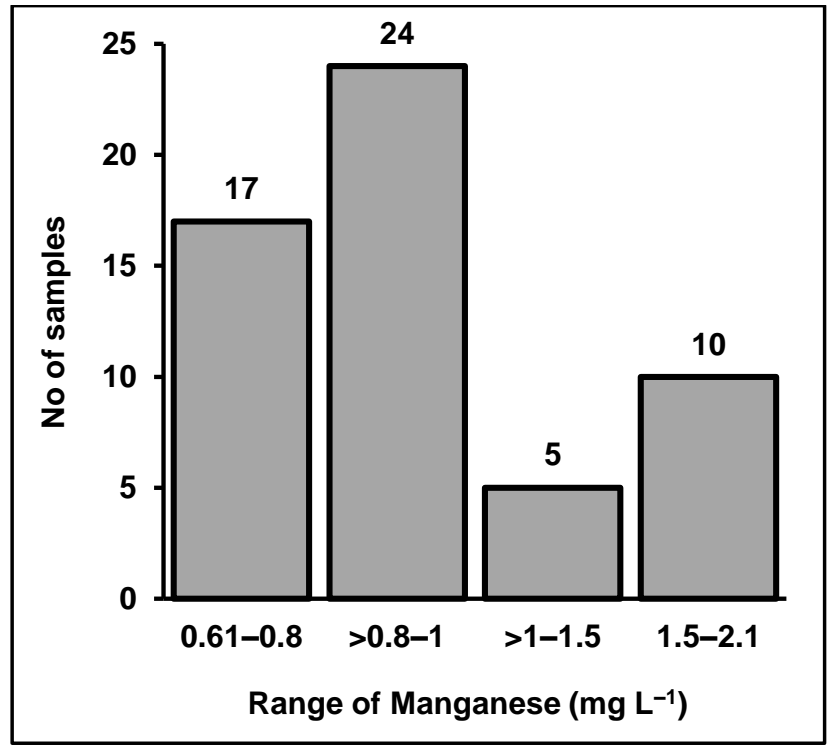

(d)

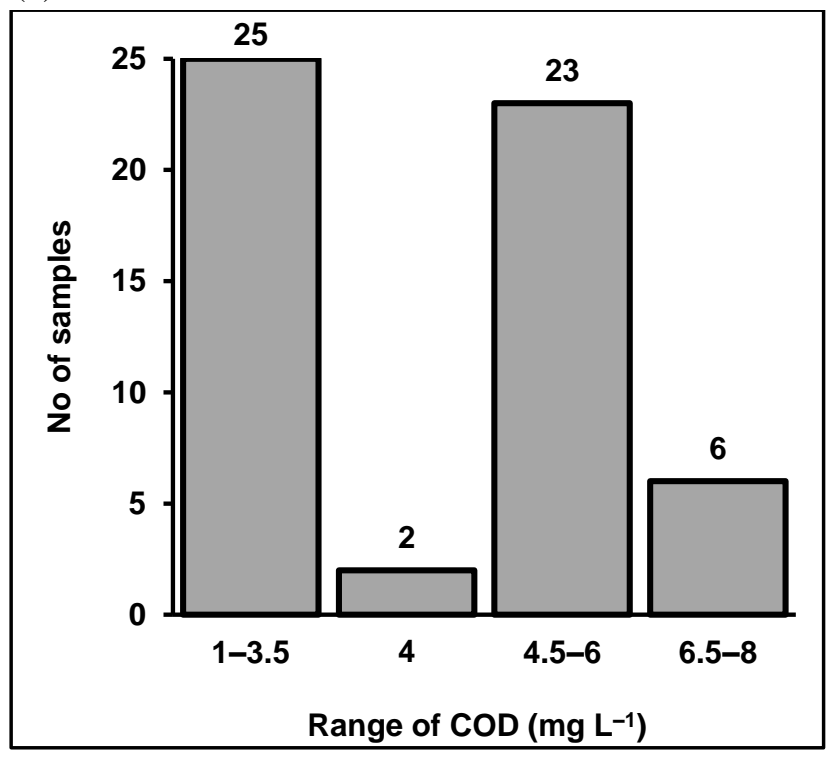


(e)

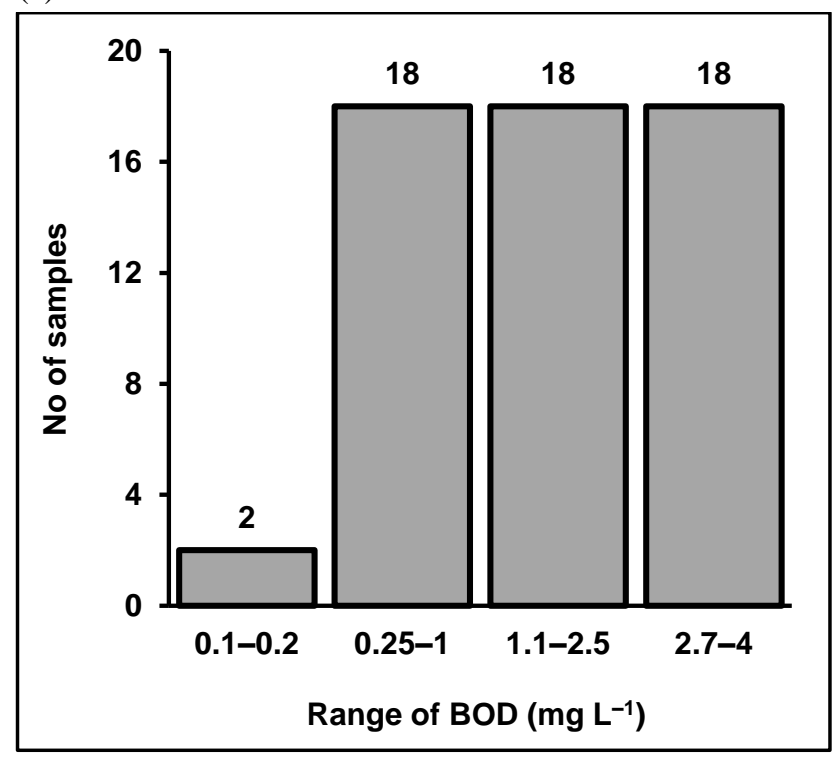

(f)

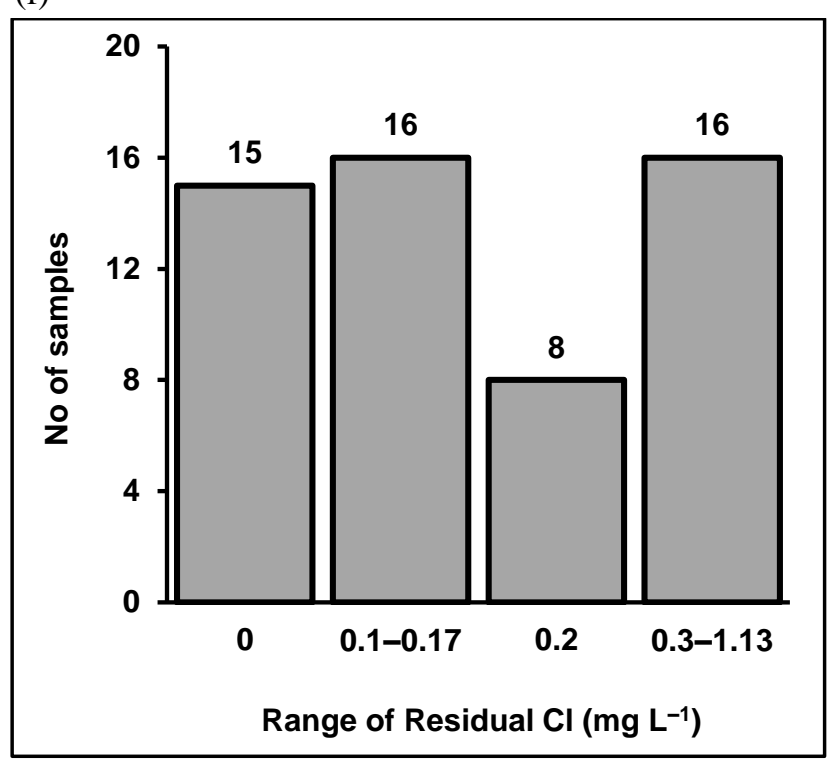

(g)

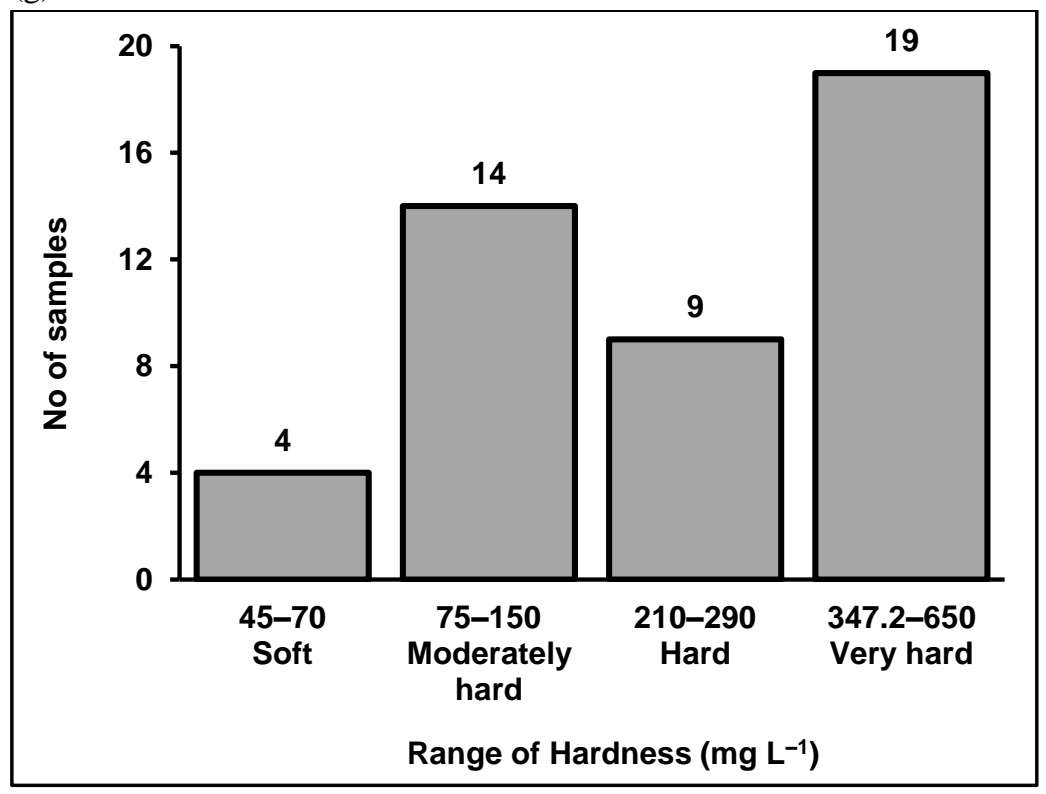

Figure 3: Representation of chemical parameters: (a) Iron, (b) Manganese, (c) Arsenic, (d) COD, (e) BOD, (f) Residual Cl, and (g) Hardness. 


\subsubsection{Analysis of microbiological parameters}

Potential causes regarding the growth of TC and E. coli in DWDSs are biofilm formation, cell detachment, sample tap contamination, damaged water treatment, and supply infrastructure. They allow the ingress of water from the surroundings (Ellis et al., 2018).

Total Coliform (TC): All samples contained TC. Thirty-one sample had the TC ranged from 15-40 CFU (100 mL $)^{-1}$, and twenty-five samples ranged from $>40-255 \mathrm{CFU}(100 \mathrm{~mL})^{-1}$. Ward 23 contained a higher amount of TC in both the sources $\left(170 \mathrm{CFU}(100 \mathrm{~mL})^{-1}\right)$, and the user points $\left(240,255\right.$, and $\left.185 \mathrm{CFU}(100 \mathrm{~mL})^{-1}\right)$. Few user points had the TC twice or thrice than that of the sources (i.e. in ward 26, 27, 29, 11, 12, 8, 9, and 19). Figure 4(a)

E. coli: Twenty-eight and twenty-two samples had E. coli ranged from 3-15 CFU (100 mL $)^{-1}$, and 16-34 CFU (100 $\mathrm{mL})^{-1}$ respectively. However, six samples contained a higher concentration $E$. coli of 40-60 CFU $(100 \mathrm{~mL})^{-1}$. The maximum and minimum values of $E$. coli from the samples were $3 \mathrm{CFU}(100 \mathrm{~mL})^{-1}$ (Sources of ward 27), and $60 \mathrm{CFU}(100 \mathrm{~mL})^{-1}(\mathrm{User}$ points of ward 29) respectively. Sources of ward 8, 30, and 14 were free from E. coli microorganisms. According to BDWSs and WHO standards, drinking and domestic water should be free from any bacteria. Figure 4(b)

So, the RCC area's water does not safe considering the microbiological aspects of water quality standards. Most microbes get shelter in the biofilm on the pipeline's inner surface in WDS (Gulati and Ghosh, 2017). This test result shows that user points contain a higher amount of bacteria than the sources. The paper explained the reasons for regrowth above. Additionally, there is a proportional relationship between high Temperature and the regrowth of microorganisms. Because organism respiration and cell growth become easier at an increased temperature. An increase in microorganisms occurring within WDS results in the decline of DO (Power and Nagy, 1999).

(a)

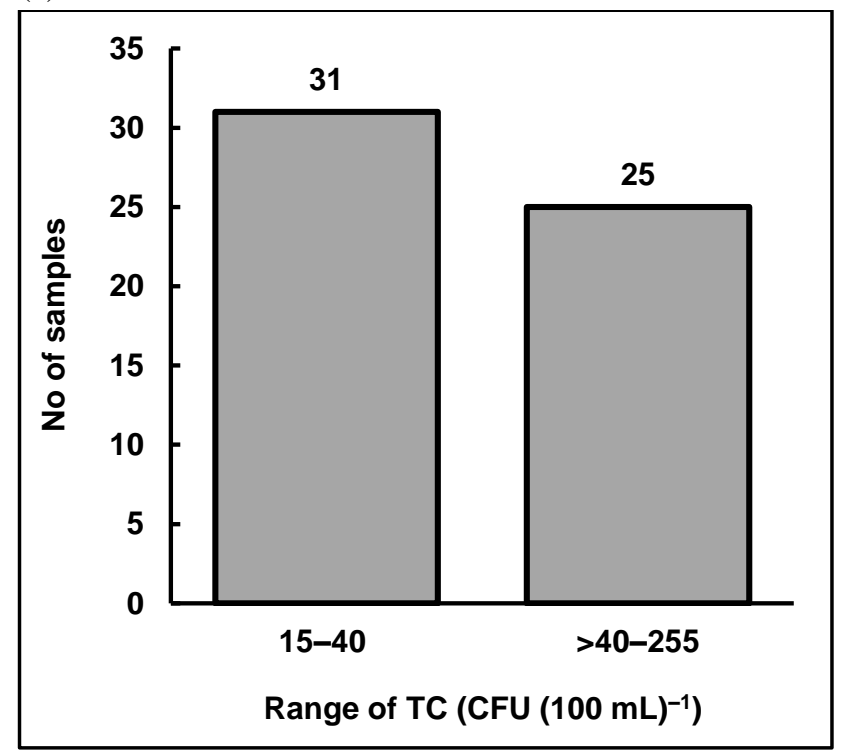

(b)

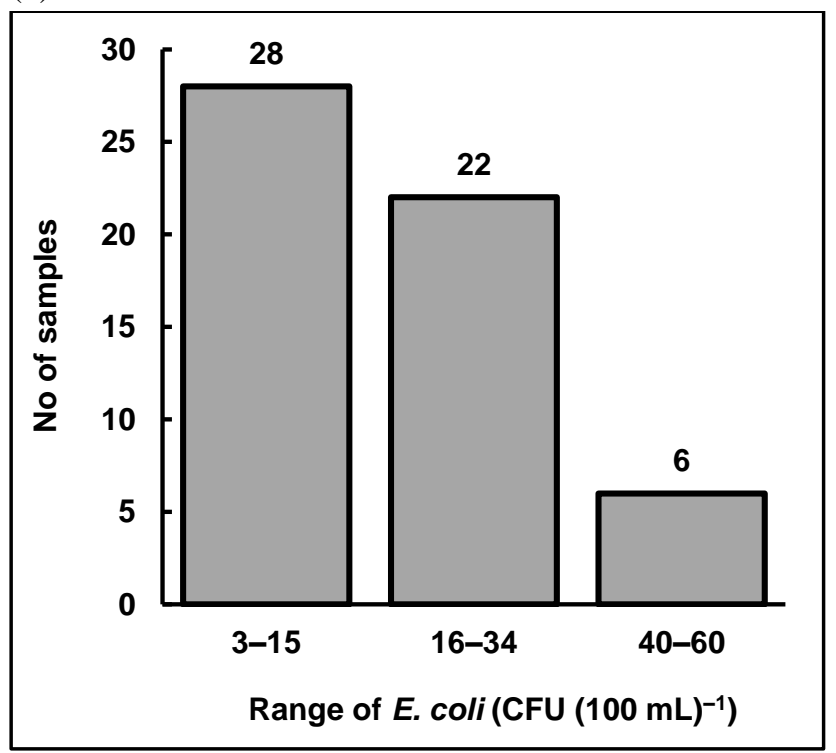

Figure 4: Representation of biological parameters: (a) TC, and (b) E. coli. 


\subsection{Statistical analysis}

The authors collected the samples from RWASA points and household samples of the RCC wards. They analysed a total of

fourteen parameters. Out of them, seven samples were chemical $(50 \%)$, five were physical $(35.71 \%)$, and two were microbiological (14.29\%) parameters.

Mean is the average of numbers, a calculated central value of a set of numbers. Standard Deviation (SD) is the degree used to quantify the difference in the dispersion of a set of data values. Standard Error of Mean (SEM) is a method of statistical data check. The SEM is the method that estimates the SD of a distribution (RICHARDI.LEVIN, 1978).

260 Table 2 shows the results of both physical and chemical parameters found in descriptive statistics [Mean \pm SD]. The table also describes the SEM. The obtained results show the characteristics of the overall water quality.

Table 2: Mean \pm SD, SEM of the standards.

\begin{tabular}{|c|c|c|c|c|c|c|c|}
\hline \multicolumn{2}{|c|}{ Type and name of parameters } & WASA & SEM & Consumer & SEM & BDWSs & $\begin{array}{c}\text { WHO } \\
\text { standards }\end{array}$ \\
\hline \multirow{5}{*}{$\begin{array}{c}\text { Physical } \\
\text { parameters }\end{array}$} & $\mathrm{pH}$ & $6.8 \pm 0.21$ & 0.03 & $6.87 \pm 0.29$ & 0.04 & $6.5-8.5$ & $6.5-8.5$ \\
\hline & Turbidity & $2.77 \pm 2.43$ & 0.37 & $5.27 \pm 6.57$ & 1.01 & $10 \mathrm{NTU}$ & $5 \mathrm{NTU}$ \\
\hline & Temperature & $26.05 \pm 2.90$ & 0.44 & $26.06 \pm 3.48$ & 0.54 & $20-30^{\circ} \mathrm{C}$ & $20-30^{\circ} \mathrm{C}$ \\
\hline & $\mathrm{EC}$ & $1264.28 \pm 349.26$ & 53.89 & $1368.21 \pm 412.78$ & 63.69 & $1200 \mu \mathrm{s} \mathrm{cm}^{-1}$ & -- \\
\hline & DO & $1.29 \pm 1.22$ & 0.19 & $1.59 \pm 1.40$ & 0.22 & $6 \mathrm{mg} \mathrm{L}^{-1}$ & -- \\
\hline \multirow{7}{*}{$\begin{array}{l}\text { Chemical } \\
\text { parameters }\end{array}$} & $\mathrm{Fe}$ & $0.69 \pm 0.66$ & 0.10 & $1.28 \pm 1.07$ & 0.16 & $0.3-1 \mathrm{mg} \mathrm{L}^{-1}$ & $0.3 \mathrm{mg} \mathrm{L}^{-1}$ \\
\hline & As & $0.01 \pm 0.01$ & 0.002 & $0.01 \pm 0.01$ & 0.001 & $0.05 \mathrm{mg} \mathrm{L}^{-1}$ & $0.01 \mathrm{mg} \mathrm{L}^{-1}$ \\
\hline & $\mathrm{Mn}$ & $0.98 \pm 0.35$ & 0.05 & $1.10 \pm 0.44$ & 0.07 & $0.1 \mathrm{mg} \mathrm{L}^{-1}$ & $0.5 \mathrm{mg} \mathrm{L}^{-1}$ \\
\hline & COD & $3.42 \pm 1.06$ & 0.25 & $3.98 \pm 1.73$ & 0.27 & $4 \mathrm{mg} \mathrm{L}^{-1}$ & -- \\
\hline & BOD & $1.67 \pm 1.09$ & 0.17 & $1.88 \pm 1.15$ & 0.18 & $0.2 \mathrm{mg} \mathrm{L}^{-1}$ & -- \\
\hline & Residual $\mathrm{Cl}$ & $0.27 \pm 0.29$ & 0.04 & $0.18 \pm 0.22$ & 0.03 & $0.2 \mathrm{mg} \mathrm{L}^{-1}$ & -- \\
\hline & Hardness & $282.73 \pm 193.73$ & 29.89 & $334.79 \pm 203.52$ & 31.40 & $\begin{array}{c}2000-500 \mathrm{mg} \\
\mathrm{L}^{-1}\end{array}$ & -- \\
\hline \multirow{2}{*}{$\begin{array}{l}\text { Biological } \\
\text { parameters }\end{array}$} & $\mathrm{TC}$ & $40.00 \pm 40.25$ & 6.21 & $71.61 \pm 65.65$ & 10.13 & $0 \mathrm{CFU} \mathrm{mL} \mathrm{m}^{-1}$ & $0 \mathrm{CFU} \mathrm{mL} \mathrm{m}^{-1}$ \\
\hline & E. coli & $8.21 \pm 9.17$ & 1.42 & $20.59 \pm 13.23$ & 2.04 & $0 \mathrm{CFU} \mathrm{mL} \mathrm{mL}^{-1}$ & $0 \mathrm{CFU} \mathrm{mL}^{-1}$ \\
\hline
\end{tabular}

Table 3: Minimum and maximum values at RWASA points and household samples.

\begin{tabular}{ccccc}
\hline \multirow{2}{*}{ Type and name of parameters } & \multicolumn{2}{c}{ RWASA points } & \multicolumn{2}{c}{ Household samples } \\
\cline { 2 - 5 } & Minimum & Maximum & Minimum & Maximum \\
\hline $\mathrm{pH}$ & 6.5 & 7.12 & 6.4 & 7.5
\end{tabular}


https://doi.org/10.5194/dwes-2020-31

Preprint. Discussion started: 13 January 2021

(c) Author(s) 2021. CC BY 4.0 License.

\begin{tabular}{|c|c|c|c|c|c|}
\hline \multirow{4}{*}{$\begin{array}{c}\text { Physical } \\
\text { parameters }\end{array}$} & Turbidity & 0.5 & 7.63 & 0.41 & 25.22 \\
\hline & Temperature & 20 & 29 & 16.5 & 30 \\
\hline & $\mathrm{EC}$ & 450 & 1600 & 425 & 1900 \\
\hline & DO & 0.25 & 5 & 0.37 & 5.5 \\
\hline \multirow{7}{*}{$\begin{array}{l}\text { Chemical } \\
\text { parameters }\end{array}$} & $\mathrm{Fe}$ & 0.03 & 2.5 & 0.04 & 3.5 \\
\hline & $\mathrm{Mn}$ & 0.6 & 1.7 & 0.64 & 2.1 \\
\hline & As & 0 & 0.03 & 0 & 0.04 \\
\hline & COD & 1 & 7 & 1.2 & 8 \\
\hline & BOD & 0.1 & 3.2 & 0.2 & 4 \\
\hline & Residual $\mathrm{Cl}$ & 0 & 1.13 & 0 & 1.1 \\
\hline & Hardness & 45 & 597 & 60 & 650 \\
\hline \multirow{2}{*}{$\begin{array}{l}\text { Biological } \\
\text { parameters }\end{array}$} & $\mathrm{TC}$ & 10 & 170 & 18 & 255 \\
\hline & E. coli & 0 & 32 & 5 & 60 \\
\hline
\end{tabular}

Table 3 shows the minimum and maximum values of RWASA points and household samples. The minimum and maximum values of water samples for $\mathrm{pH}$ ranged from 6.5-7.12 and 6.4-7.5, turbidity from 0.5-7.63 NTU and 0.41-25.22 NTU, temperature from $20-29^{\circ} \mathrm{C}$ and $16.5-30^{\circ} \mathrm{C}$, EC from $450-1600 \mu \mathrm{s} \mathrm{cm}^{-1}$ and $425-1900 \mu \mathrm{sm}^{-1}$, DO from $0.25-5 \mathrm{mg} \mathrm{L}^{-1}$ and $0.37-5.5 \mathrm{mg} \mathrm{L}^{-1}$ at the RWASA points and household samples respectively. The amount of Fe ranged from $0.03-2.5 \mathrm{mg} \mathrm{L}^{-1}$ and 0.04-3.5 $\mathrm{mg} \mathrm{L}^{-1}$, Mn from 0.6-1.7 $\mathrm{mg} \mathrm{L}^{-1}$ and 0.64-2.1 $\mathrm{mg} \mathrm{L}^{-1}$, COD from 1-7 $\mathrm{mg} \mathrm{L}^{-1}$ and 1.2-8 $\mathrm{mg} \mathrm{L}^{-1}$, BOD from 0.1$3.2 \mathrm{mg} \mathrm{L}^{-1}$ and $0.2-4 \mathrm{mg} \mathrm{L}^{-1}$, Residual $\mathrm{Cl}$ from $0-1.13 \mathrm{mg} \mathrm{L}^{-1}$ and $0-1.1 \mathrm{mg} \mathrm{L}^{-1}$, hardness from $45-597 \mathrm{mg} \mathrm{L}^{-1}$ and $60-650$ $275 \mathrm{mg} \mathrm{L}^{-1}$, TC from 10-170 $\mathrm{mg} \mathrm{L}^{-1}$ and $18-255 \mathrm{mg} \mathrm{L}^{-1}$, E. coli from 0-32 $\mathrm{mg} \mathrm{L}^{-1}$ and 5-60 $\mathrm{mg} \mathrm{L}^{-1}$, As from 0-0.03 $\mathrm{mg} \mathrm{L}^{-1}$ and 0-0.04 $\mathrm{mg} \mathrm{L}^{-1}$ respectively at the RWASA points and household samples following the WHO (2006) standards and BDWSs.

\subsubsection{Correlation matrix of the physicochemical parameters}

Pearson correlation (r) verifies the co-relationship between the physical, chemical, and microbiological parameters of different water sources. The Pearson correlation finds a correlation between at least two continuous variables. The correlation value ranges from -1.00 to +1.00 . There are two kinds of correlation: (1) Positive correlation and (2) Negative correlation. The Pearson correlation values can range between 0.00 (No correlation), and \pm 1.00 (Strong correlation). More precisely, the parameters having $\mathrm{r}=0.7$ are strongly correlated. The parameters of $\mathrm{r}$-value between 0.5 and 0.7 have a moderate correlation (Springer paper). The test revealed several significant interactions among the study area water samples' physical, chemical, and microbiological variables. Many parameters showed different correlations at the water from the RWASA points and household samples (Table 4 and Table 5).

Table 4: First correlation between the physical, chemical, and microbiological parameters using Pearson correlation (r).

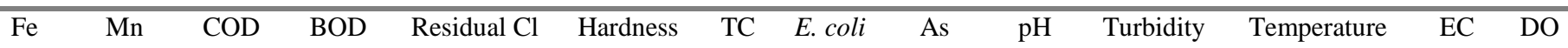


https://doi.org/10.5194/dwes-2020-31

Preprint. Discussion started: 13 January 2021

(c) Author(s) 2021. CC BY 4.0 License.

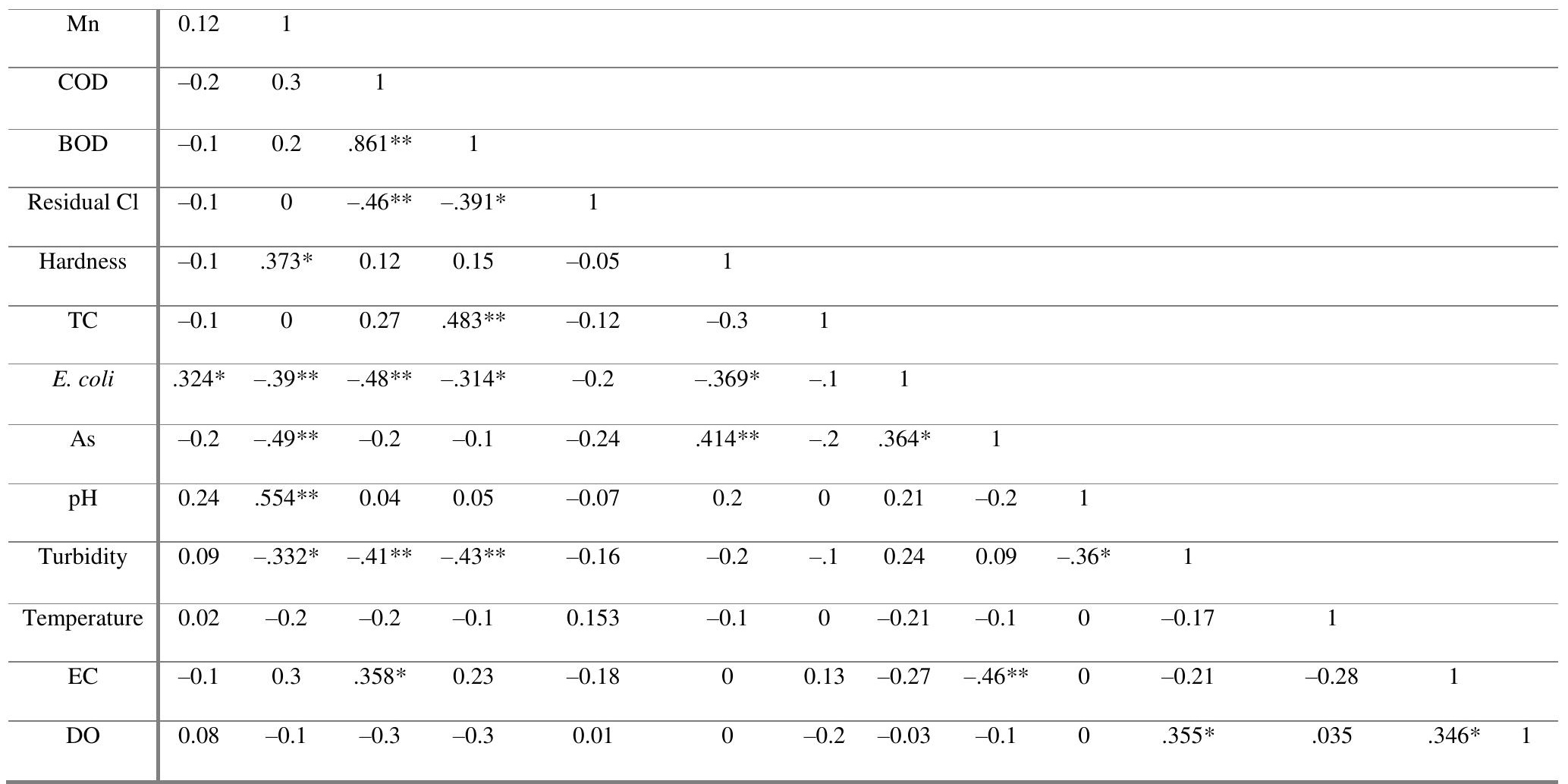

*Correlation is significant at the 0.05 level (2-tailed)

$* *$ Correlation is significant at the 0.01 level (2-tailed)

From table 4, Fe is correlated positively with $\mathrm{Mn}(\mathrm{r}=0.12)$, E. coli $(\mathrm{r}=0.324), \mathrm{pH}(\mathrm{r}=0.24)$, turbidity $(\mathrm{r}=0.09)$, temperature $(\mathrm{r}=0.02)$, DO $(\mathrm{r}=0.08)$, and negatively correlated with COD $(-0.2)$, BOD $(-0.1)$, Residual Cl $(-0.1)$, hardness $(-0.1)$, TC $(-$ $0.1)$. Mn is positively correlated with COD (0.3), BOD (0.2), hardness (.373), pH (.554), EC (0.3), no correlation with Residual

$295 \mathrm{Cl}(0)$, TC (0), and negatively correlated with E. coli (-.399), As (-.494), turbidity (-.332), temperature ( -0.2$)$, DO (-0.1). COD is positively correlated with BOD (.861), hardness $(0.12)$, TC (0.27), pH (0.04), EC (.358), and negatively correlated with Residual $\mathrm{Cl}(-.458)$, E. coli (-.478), As (-0.2), turbidity (-.410), temperature (-0.2), DO (-0.3). BOD is positively correlated with hardness (0.15), TC (.483), $\mathrm{pH}(0.05)$, EC (0.23), and negatively correlated with Residual Cl (-.391), E. coli $(-.314)$, As $(-0.1)$, turbidity (-.429), temperature $(-0.1)$, DO $(-0.3)$.

300 Residual $\mathrm{Cl}$ is positively correlated with temperature (0.153), DO (0.01), and negatively correlated with hardness ( -0.05$)$, TC $(-0.12)$, E. coli $(-0.2)$, As $(-0.24), \mathrm{pH}(-0.07)$, turbidity $(-0.16)$, EC $(-0.18)$. Hardness is positively correlated with As (.414), $\mathrm{pH}(0.2)$, no correlation with EC (0), DO (0), and negatively correlated with turbidity $(-0.2)$, temperature $(-0.1)$, TC $(-$ $0.3)$, E. coli (-.369). TC is positively correlated with EC (0.13), no correlation with $\mathrm{pH}(0)$, temperature $(0)$, and negatively correlated with E. coli $(-0.1)$, As $(-0.2)$, turbidity $(-0.1)$, DO (-0.2). E. coli is positively correlated with As $(.364)$, pH $(0.21)$,

305 turbidity (0.24), and negatively correlated with temperature $(-0.21)$, EC $(-0.27)$, DO ( -0.03$)$. Whereas, As is positively correlated with turbidity (0.09), and negatively correlated with $\mathrm{pH}(-0.2)$, temperature $(-0.1), \mathrm{EC}(-.464), \mathrm{DO}(-0.1)$. $\mathrm{pH}$ has no correlation with temperature $(0), \mathrm{EC}(0), \mathrm{DO}(0)$, and is negatively correlated with turbidity (-.362). Turbidity is positively 
https://doi.org/10.5194/dwes-2020-31

Preprint. Discussion started: 13 January 2021

(c) Author(s) 2021. CC BY 4.0 License.

(c) (i)

correlated with DO (.355) and negatively correlated with temperature (-0.17), EC (-0.21). Temperature is positively correlated with DO (0.035) and negatively correlated with EC (-0.28). DO is positively correlated with EC (.346).

Table 5: Second correlation between the physical, chemical, and microbiological parameters using Pearson correlation (r).

\begin{tabular}{|c|c|c|c|c|c|c|c|c|c|c|c|c|c|c|}
\hline & $\mathrm{Fe}$ & Mn & COD & BOD & Residual Cl & Hardness & $\mathrm{TC}$ & E. coli & As & $\mathrm{pH}$ & Turbidity & Temperature & $\mathrm{EC}$ & DO \\
\hline $\mathrm{Fe}$ & 1 & & & & & & & & & & & & & \\
\hline COD & 0 & .2 & 1 & & & & & & & & & & & \\
\hline BOD & .09 & .3 & $.79 * *$ & 1 & & & & & & & & & & \\
\hline Residual Cl & 0 & -0.1 & $-.5 * *$ & $-.5 * *$ & 1 & & & & & & & & & \\
\hline Hardness & 0 & $.43 * *$ & .08 & 0.13 & .028 & 1 & & & & & & & & \\
\hline $\mathrm{TC}$ & -0.2 & -0.1 & $.374 *$ & $.61 * *$ & $-.315^{*}$ & -0.2 & 1 & & & & & & & \\
\hline E. coli & .29 & -0.2 & $-.36^{*}$ & $-.4 * *$ & 0.11 & $-.321 *$ & -0.2 & 1 & & & & & & \\
\hline As & 0.1 & -0.2 & 0.21 & 0.19 & -0.13 & 0.2 & 0 & 0.15 & 1 & & & & & \\
\hline $\mathrm{pH}$ & .12 & $.41 * *$ & 0 & 0.13 & -0.01 & 0.3 & 0 & -0.03 & -0.3 & 1 & & & & \\
\hline Turbidity & 0.2 & $-0.36^{*}$ & $-0.35^{*}$ & $-0.52 * *$ & .164 & -0.2 & $-0.35^{*}$ & $0.44 * *$ & -0.1 & 0 & 1 & & & \\
\hline Temperature & $-.36 *$ & $-0.37 *$ & -0.2 & 0 & .038 & -0.1 & 0.15 & $-0.41 * *$ & 0 & 0 & $-0.41 * *$ & 1 & & \\
\hline $\mathrm{EC}$ & -0.1 & $.331 *$ & $.48 * *$ & 0.3 & -0.19 & 0.1 & 0.2 & -0.25 & -0.1 & 0 & $-0.34 *$ & -0.18 & 1 & \\
\hline DO & 0.03 & -0.2 & -0.2 & -0.1 & 0.15 & 0.2 & -0.2 & -0.12 & 0.05 & 0 & 0.052 & .177 & $.33^{*}$ & 1 \\
\hline
\end{tabular}

*Correlation is significant at the 0.05 level (2-tailed)

**Correlation is significant at the 0.01 level (2-tailed)

315

From table 5, Fe is correlated positively with $\mathrm{Mn}(\mathrm{r}=0.22)$, BOD $(0.09)$, E. coli $(0.29)$, As $(0.1), \mathrm{pH}(\mathrm{r}=0.12)$, turbidity $(0.2)$, DO (0.03), no correlation with COD (0), Residual $\mathrm{Cl}(0)$, hardness $(0)$, and negatively correlated with temperature $(\mathrm{r}=-.363)$, TC (-0.2), EC (-0.1). Mn is positively correlated with COD (0.2), BOD (0.3), hardness (.432), EC (0.331), pH (0.41), and 320 negatively correlated with Residual $\mathrm{Cl}(-.1)$, E. coli (-.2), turbidity (-.36), temperature ( -0.37$), \mathrm{DO}(-0.2)$. COD is positively correlated with BOD (.792), TC (0.374), EC (.48), hardness (0.08), As (0.21), no correlation with pH (0), and negatively correlated with Residual $\mathrm{Cl}(-.458)$, E. coli (-.36), turbidity (-.35), temperature (-0.2), DO (-0.2). BOD is positively correlated with hardness (0.13), TC (.61), $\mathrm{pH}(0.13)$, As (0.19), EC (0.3), no correlation with temperature (0), and negatively correlated with Residual $\mathrm{Cl}(-0.5)$, turbidity (-.522), E.coli (-.4), DO (-0.1). Residual $\mathrm{Cl}$ is positively correlated with hardness $(0.028)$, 325 DO (0.148), E.coli (0.11), turbidity (0.164), temperature (0.038), and negatively correlated with TC (-.315), As (-0.13), pH 
(-0.01), EC (-0.19). Hardness is positively correlated with As (.2), $\mathrm{pH}(0.3)$, EC (.1), DO (0.2), and negatively correlated with turbidity $(-0.2)$, temperature $(-0.1)$, TC $(-0.2)$, E.coli $(-.321)$.

$\mathrm{TC}$ is positively correlated with temperature (.15), $\mathrm{EC}(0.2)$, no correlation with As (0), $\mathrm{pH}(0)$, and negatively correlated with E.coli $(-0.2)$, turbidity $(-0.348)$, DO ( -0.2$)$. E.coli is positively correlated with As (.15), turbidity $(0.441)$, and negatively correlated with temperature $(-0.412)$, EC $(-0.25)$, DO $(-0.12)$, $\mathrm{pH}(-0.03)$. Whereas, As is positively correlated with DO (0.05), no correlation with temperature (0), and negatively correlated with turbidity $(-.1)$, $\mathrm{pH}(-0.3)$, EC (-.1). Turbidity is positively correlated with DO (.052) and negatively correlated with temperature (-0.411), EC (-0.339). pH has no correlation with temperature (0), EC (0), DO (0), and turbidity (0). Temperature is positively correlated with DO (0.177) and negatively correlated with EC (-0.18). DO is positively correlated with turbidity (0.052), temperature (0.177), EC (.33).

The presence of specific pollution indicators influences the presence of or increase in some other parameters. The increase in one physical or chemical parameter indicates the increase or decrease of another parameter. For example, a higher TC means more cations than anions in water. The EC of water increases with more ions in water. We can ultimately determine the EC concentration through measuring the $\mathrm{EC}$ of water.

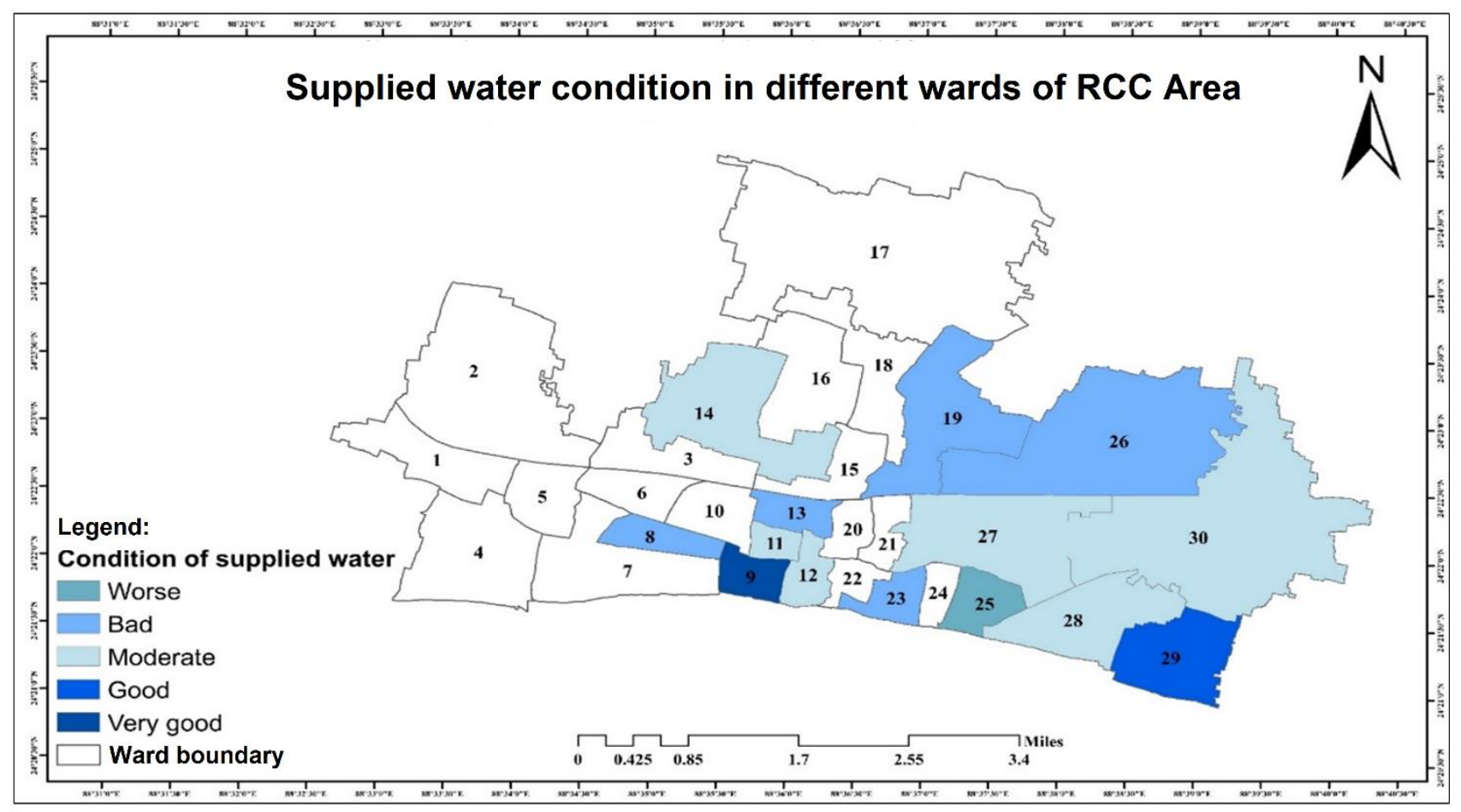

Figure 5: Supplied water condition in the wards of RCC Area.

In Fig. 5, the authors ranked the supplied water conditions based on water parameters and standards' quality. They termed the conditions following the weighted-index method. According to Fig. 5, they found water to condition the best in ward 9 (i.e. very good), and ward 29 (i.e. good). On the other hand, the worst-conditioned water existed in ward 25. 


\subsection{Health effects}

The concentration of $\mathrm{Mn}$ in a water body is associated with lower memory, attention, motor functions, mathematics achievement scores, perceptual reasoning, working memory, and behaviour problems. Moreover, epidemiological evidence and previous reports anticipate that elevated Mn concentration in drinking water is responsible for lower IQ in a group of school-aged children of 6-13 years (Dion et al., 2018). A high concentration of the metals (Coupling of Fe and Mn) creates the major esthetic problems that lead to taste and odour problems. Elevated concentration causes harmful health effects (Ander et al., 2016). The taste (Organoleptic problem) is affected when Fe's concentration is above $0.3 \mathrm{mg} \mathrm{L}^{-1}$. High Fe in the DWDSs and its ingestion can cause hemochromatosis with symptoms like chronic fatigue, arthritis, heart disease, cirrhosis, diabetes, thyroid disease, impotence, and sterility (Khan et al., 2013). The water of hardness below $300 \mathrm{mg} \mathrm{L}^{-1}$, is portable. Nevertheless, it causes gastrointestinal irritation beyond this limit.

Biofilms create taste and odour problems in the distributed water. Top categories of E.coli are not harmful, but some can cause diarrhoea, abdominal pain, fever, sometimes vomiting, and urine infections. Furthermore, certain types of E.coli infection may lead to kidney failure (What to know about E. coli infection, 2017). Bacterial gastrointestinal diseases like cholera, salmonellosis, and shigellosis transmit through water. Undesirable pathogens in DWDSs are responsible for the outbreak of water-borne diseases (Sharif et al., 2017). Salmonella typhi and Salmonella paratyphi cause typhoid fever (Jayaswal et al., 2018). There is an intimate relationship between public health and water. People suffer from various waterborne diseases consuming poor-quality supplied water by RWASA. The questionnaire survey reported the percentage of RCC people suffered from various types of diseases like diarrhoea, cholera, typhoid, mental disorder, and other problems as $45 \%$, $25 \%, 15 \%, 55 \%$, and $15 \%$ respectively (Fig. 6).

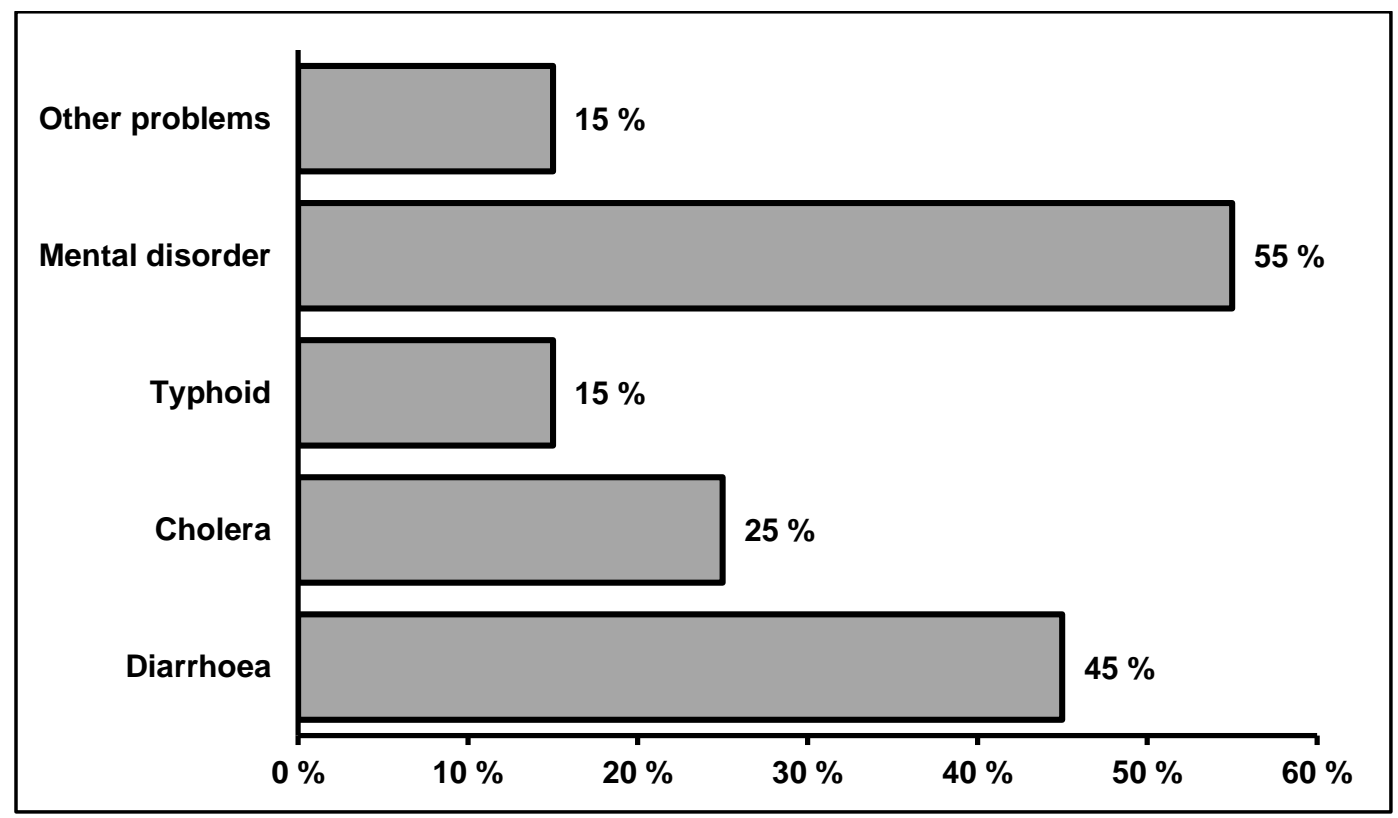

Figure 6: Percentage of various diseases from the questionnaire survey. 


\section{Conclusions}

370 Water quality deterioration of RWASA sources occurred during the household storage. The concerned authority poorly practised the regular monitoring of supplied water quality. Deteriorated water quality resulted in the outbreak of various waterborne diseases. User points contained a higher amount of bacteria than the sources. Wards with lesser DO and Residual $\mathrm{Cl}$ (i.e. ward 8, 9, and 3) indicate a higher amount of microorganisms, BOD, and COD. So, the parameters DO, Residual Cl, TC, and EC have an apparent interrelationship. All samples contained a higher concentration of Mn. Majority of the samples had a

375 higher amount of $\mathrm{Fe} . \mathrm{pH}$, temperature, and colour were within the allowable range. The study also found elevated concentration of BOD and COD as per the BDWSs and WHO standards.

Limitations of the study. The authors cannot investigate Pseudomonas Aeromonas, Artrobacter, Caulobacter, Klebsiella Bacillus, Enterobacter, Citrobacter, and Acinetobacter Prosthescomicrobium, Alcaligenes, Serratior, and Actinolegionella

380 due to insufficient lab facilities. The knowledge of water storage lengths at the households, length of pipes from tap to consumer storage, no fittings, and cross-connections are unknown.

Code availability. Application of SPSS software.

Data availability. The authors collected the necessary data from a field survey.

Author contributions. SAP was the investigator and contributed to the statistical analysis. AH and HIT contributed to the investigation, and involved in the statistical analysis. HMR involved in the supervision and contributed to the methodology. HIT prepared the manuscript with contributions from all co-authors.

Competing interests. The authors declare that they have no conflict of interest.

Acknowledgements. The authors wish to thank the authority of RWASA, the operational staff of public health lab, Rajshahi, and non-teaching staff of Rajshahi University of Engineering \& Technology (RUET) for providing necessary laboratory 395 facilities, their constant encouragement, and support. They are also highly indebted to Assistant Engineer of RWASA, Md. Mahbubur Rahman for the painstaking endeavour to go through the manuscript.

\section{References}

400 Color, taste and odor problems in drinking water, Washington State Department of Health, 2018.

Guidelines for drinking-water quality, World Health Organization (WHO), 1-540, 2004.

Turbidity and water: https://www.usgs.gov/special-topic/water-science-school/science/turbidity-and-water?qtscience_center_objects=0\#qt-science_center_objects, access: 30 August, 2020.

What to know about E. coli infection: https://www.medicalnewstoday.com/articles/68511, access: 30 August, 2020, 2017. 
https://doi.org/10.5194/dwes-2020-31

Preprint. Discussion started: 13 January 2021

(c) Author(s) 2021. CC BY 4.0 License.

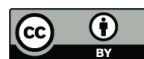

Agathokleous, A., and Christodoulou, S.: The impact of intermittent water supply policies on urban water distribution networks International Conference on Efficient \& Sustainable Water Systems Management toward Worth Living Development, 2nd EWaS, 2016, 204-211,

Akoto, O., Gyamfi, O., Darko, G., and Barnes, V. R.: Changes in water quality in the Owabi water treatment plant in Ghana, Appl Water Sci 7, 175-186, 10.1007/s13201-014-0232-4, 2017.

AL-Dulaimi, G. A., and Younes, M. K.: Assessment of potable water quality in Baghdad City, Iraq, Air, Soil and Water Research, 10, 1-5, https://doi.org/10.1177/1178622117733441, 2017.

Alam, M. F., Dafader, N. C., Sultana, S., Rahman, N., and Taheri, T.: Physico-chemical analysis of the bottled drinking water available in the Dhaka City of Bangladesh Journal of Materials and Environmental Sciences, 8, 2076-2083, 2017.

Alom, M. M., and Habib, M. Z.: Observation of water quality and supply system in Dhaka City, Bangladesh, IOSR Journal of Mechanical and Civil Engineering (IOSR-JMCE), 13, 23-27, 10.9790/1684-1303062327 2016.

Ander, E. L., Watts, M. J., Smedley, P. L., Hamilton, E. M., Close, R., Crabbe, H., and Fletcher, T., et al.: Variability in the chemistry of private drinking water supplies and the impact of domestic treatment systems on water quality, Environ Geochem Health, 38, 1313-1332, https://doi.org/10.1007/s10653-016-9798-0, 2016.

Bari, M. N., and Sarkar, I. H.: Quality assessment of pond water in Rajshahi City, International Conference on Planning, Architecture and Civil Engineering (ICPACE), Rajshahi University of Engineering \& Technology, Rajshahi, Bangladesh, 2017, 131-135,

Benson, R., Conerly, O. D., Sander, W., Batt, A. L., Boone, J. S., Furlong, E. T., and Glassmeyer, S. T., et al.: Human health screening and public health significance of contaminants of emerging concern detected in public water supplies, Science of The Total Environment, 579, 1643-1648, https://doi.org/10.1016/j.scitotenv.2016.03.146, 2017.

Cabral, J. P. S.: Water microbiology. Bacterial pathogens and water, Int. J. Environ. Res. Public Health, 7, 3657-3703, https://doi.org/10.3390/ijerph7103657, 2010.

Chalchisa, D., Megersa, M., and Beyene, A.: Assessment of the quality of drinking water in storage tanks and its implication on the safety of urban water supply in developing countries, Environmental Systems Research, 6, 12, 10.1186/s40068017-0089-2, 2017.

Dion, L.-A., Saint-Amour, D., Sauvé, S., Barbeau, B., Mergler, D., and Bouchard, M. F.: Changes in water manganese levels and longitudinal assessment of intellectual function in children exposed through drinking water, NeuroToxicology, 64, 118-125, https://doi.org/10.1016/j.neuro.2017.08.015, 2018.

Doull, J., Andelman, J. B., Buhler, D. R., Characklis, W. G., Christman, R. F., and Cohen, S. D., et al.: Biological quality of water in the distribution system, in: Drinking Water and Health, Washington (DC): National Academies Press (US), National Research Council (US) Safe Drinking Water Committee, 1982.

Douterelo, I., Jackson, M., Solomon, C., and Boxall, J.: Microbial analysis of in situ biofilm formation in drinking water distribution systems: implications for monitoring and control of drinking water quality, Appl Microbiol Biotechnol, 100, 3301-3311 10.1007/s00253-015-7155-3, 2016.

Edokpayi, J. N., Rogawski, E. T., Kahler, D. M., Hill, C. L., Reynolds, C., Nyathi, E., and Smith, J. A., et al.: Challenges to sustainable safe drinking water: A case study of water quality and use across seasons in rural communities in Limpopo Province, South Africa, Water, 10, https://doi.org/10.3390/w10020159, 2018. 
https://doi.org/10.5194/dwes-2020-31

Preprint. Discussion started: 13 January 2021

(c) Author(s) 2021. CC BY 4.0 License.

(c) (i)

Ellis, K., Gowdy, C., Jakomis, N., Ryan, B., Thom, C., Biggs, C. A., and Speight, V.: Understanding the costs of investigating coliform and E. coli detections during routine drinking water quality monitoring, Urban Water Journal, 15, 101-108, https://doi.org/10.1080/1573062X.2017.1398762, 2018.

Erickson, J. J., Smith, C. D., Goodridge, A., and Nelson, K. L.: Water quality effects of intermittent water supply in Arraiján, Panama, Water Research, 114, 338-350, https://doi.org/10.1016/j.watres.2017.02.009, 2017.

Etim, E. E., Odoh, R., Itodo, A. U., Umoh, S. D., and Lawal, U.: Water quality index for the assessment of water quality from different sources in the Niger Delta Region of Nigeria, Frontiers in Science, 3, 89-95, 10.5923/j.fs.20130303.02, 2013.

Fahmida, K., Lemon, M. H. R., Islam, M. S., and Kader, M. A.: Assessment of supplied water quality of Khulna WASA of Bangladesh, International Conference on Mechanical, Industrial and Materials Engineering (ICMIME), Rajshahi University of Engineering \& Technology, Rajshahi, Bangladesh, 2013, 852-857,

Falconi, T. M. A., Kulinkina, A. V., Mohan, V. R., Francis, M. R., Kattula, D., Sarkar, R., and Ward, H., et al.: Quantifying tap-to-household water quality deterioration in urban communities in Vellore, India: The impact of spatial assumptions, International Journal of Hygiene and Environmental Health, 220, 29-36, https://doi.org/10.1016/j.ijheh.2016.09.019, 2017.

Fernández-Navarro, P., Villanueva, C. M., García-Pérez, J., Boldo, E., Goñi-Irigoyen, F., Ulibarrena, E., and Rantakokko, P., et al.: Chemical quality of tap water in Madrid: multicase control cancer study in Spain (MCC-Spain), Environ Sci Pollut Res, 24, 4755-4764, https://doi.org/10.1007/s11356-016-8203-y, 2017.

Guettaf, M., Maoui, A., and Ihdene, Z.: Assessment of water quality: a case study of the Seybouse River (North East of Algeria), Appl Water Sci, 7, 295-307, 10.1007/s13201-014-0245-z, 2017.

Gulati, P., and Ghosh, M.: Biofilm forming ability of Sphingomonas paucimobilis isolated from community drinking water systems on plumbing materials used in water distribution, Journal of Water \& Health, 15, 942-954, https://doi.org/10.2166/wh.2017.294, 2017.

Hossain, M. L., Nahida, S. K. N., and Hossain, M. I.: Water quality status of recreational spots in Chittagong City, Journal of Water Resources and Ocean Science, 3, 38-44, 10.11648/j.wros.20140303.12, 2014.

J, A., B, G., and N, S.: Drinking water quality assessment, J Nepal Health Res Counc, 10, 192-196, 2012.

Jayaswal, K., Sahu, V., and Gurjar, B. R.: Water pollution, human health and remediation, in: Water Remediation. Energy, Environment, and Sustainability, Bhattacharya S., Gupta A., Gupta A., Pandey A. ed., Springer, Singapore, 2018.

Khan, S., Shahnaz, M., Jehan, N., Rehman, S., Shah, M. T., and Din, I.: Drinking water quality and human health risk in Charsadda district, Pakistan, Journal of Cleaner Production, 60, 93-101, https://doi.org/10.1016/j.jclepro.2012.02.016, 2013.

Kumar, P., Masago, Y., Mishra, B. K., Jalilov, S., Emam, A. R., Kefi, M., and Fukushi, K.: Current assessment and future outlook for water resources considering climate change and a population burst: A case study of Ciliwung River, Jakarta City, Indonesia, Water, 9, https://doi.org/10.3390/w9060410, 2017.

475 Lee, J.-Y., Kwon, K. D., and Raza, M.: Current water uses, related risks, and management options for Seoul megacity, Korea, Environmental Earth Sciences, 77, https://doi.org/10.1007/s12665-017-7192-6, 2018. 
https://doi.org/10.5194/dwes-2020-31

Preprint. Discussion started: 13 January 2021

(c) Author(s) 2021. CC BY 4.0 License.

Liu, G., Zhang, Y., Knibbe, W.-J., Feng, C., Liu, W., Medema, G., and Meer, W. v. d.: Potential impacts of changing supplywater quality on drinking water distribution: A review, Water Research, 116, 135-148, https://doi.org/10.1016/j.watres.2017.03.031, 2017a.

Liu, J., Ren, H., Ye, X., Wang, W., Liu, Y., Lou, L., and Cheng, D., et al.: Bacterial community radial-spatial distribution in biofilms along pipe wall in chlorinated drinking water distribution system of East China, Appl Microbiol Biotechnol 101, 749-759, https://doi.org/10.1007/s00253-016-7887-8, 2017 b.

Liu, Z.-h., Yin, H., and Dang, Z.: Do estrogenic compounds in drinking water migrating from plastic pipe distribution system pose adverse effects to human? An analysis of scientific literature, Environ Sci Pollut Res, 24, 2126-2134, https://doi.org/10.1007/s11356-016-8032-z, 2017c.

Liyanage, C. P., and Yamada, K.: Impact of population growth on the water quality of natural water bodies, sustainability, 9 , https://doi.org/10.3390/su9081405, 2017.

Mangi, S. A., Sohu, S., Soomro, F. A., Abdullah, A. H., and Nagapan, S.: Assessment of Physicochemical parameters for the drinking water quality in the vicinity of Nawabshah City, Sindh, Pakistan, ENGINEERING SCIENCE AND TECHNOLOGY INTERNATIONAL RESEARCH JOURNAL, 1, 10-14, 2017.

Martínez-Santos, P., Martín-Loeches, M., García-Castro, N., Solera, D., Díaz-Alcaide, S., Montero, E., and García-Rincón, J.: A survey of domestic wells and pit latrines in rural settlements of Mali: Implications of on-site sanitation on the quality of water supplies, International Journal of Hygiene and Environmental Health, 220, 1179-1189, https://doi.org/10.1016/j.jheh.2017.08.001, 2017.

Memon, M., Soomro, M. S., Akhtar, M. S., and Memon, K. S.: Drinking water quality assessment in Southern Sindh (Pakistan), Environ Monit Assess, 177, 39-50, https://doi.org/10.1007/s10661-010-1616-z, 2011.

Oyem, H. H., Oyem, I. M., and Ezeweali, D.: Temperature, pH, electrical conductivity, total dissolved solids and chemical oxygen demand of groundwater in Boji-BojiAgbor/Owa area and immediate suburbs, Resrch Jourl of Environtal Science, 444-450, 103923/rjes.2014, 2014.

Power, K. N., and Nagy, L. A.: Relationship between bacterial regrowth and some physical and chemical parameters within Sydney's drinking water distribution system, Water Research, 33, 741-750, https://doi.org/10.1016/S00431354(98)00251-6, 1999.

Rahman, M. M.: Surface water quality in Rajshahi City, The Journal of Geo-Environment, 4, 15-22, 2004.

Robinne, F.-N., Bladon, K. D., Miller, C., Parisien, M.-A., Mathieu, J., and Flannigan, M. D.: A spatial evaluation of global wildfire-water risks to human and natural systems, Science of The Total Environment, 610-611, 1193-1206, https://doi.org/10.1016/j.scitotenv.2017.08.112, 2018.

Sharif, M. N., Farahat, A., Haider, H., Al-Zahrani, M. A., Rodriguez, M. J., and Sadiq, R.: Risk-based framework for optimising residual chlorine in large water distribution systems, Environ Monit Assess, 189, https://doi.org/10.1007/s10661-017-5989-0, 2017.

510 Shigut, D. A., Liknew, G., Irge, D. D., and Ahmad, T.: Assessment of physico-chemical quality of borehole and spring water sources supplied to Robe Town, Oromia region, Ethiopia, Appl Water Sci, 7, 155-164, 10.1007/s13201-016-0502-4, 2017. 
https://doi.org/10.5194/dwes-2020-31

Preprint. Discussion started: 13 January 2021

(c) Author(s) 2021. CC BY 4.0 License.

(c) (1)

Vairavamoorthy, K., Yan, J., Galgale, H. M., and Gorantiwar, S. D.: IRA-WDS: A GIS-based risk analysis tool for water distribution systems, Environmental Modelling \& Software, 22, 951-965, https://doi.org/10.1016/j.envsoft.2006.05.027, 2007.

515 Wang, F., Li, W., Li, Y., Zhang, J., Chen, J., Zhang, W., and Wu, X.: Molecular analysis of bacterial community in the tap water with different water ages of a drinking water distribution system, Front. Environ. Sci. Eng., 12, https://doi.org/10.1007/s11783-018-1020-4, 2018.

Zhang, C., Li, C., Zheng, X., Zhao, J., He, G., and Zhang, T.: Effect of pipe materials on chlorine decay, trihalomethanes formation, and bacterial communities in pilot-scale water distribution systems, Int. J. Environ. Sci. Technol., 14, 85-94, https://doi.org/10.1007/s13762-016-1104-2, 2017.

Zhou, X., Zhang, K., Zhang, T., Li, C., and Mao, X.: An ignored and potential source of taste and odor (T \& O) issues-biofilms in drinking water distribution system (DWDS), Appl Microbiol Biotechnol 101, 3537-3550, https://doi.org/10.1007/s00253-017-8223-7, 2017. 